\title{
An roGFP2-Based Bacterial Bioreporter for Redox Sensing of Plant Surfaces
}

\author{
Ting-Hang Liu, $, 2,3,4$ Mohammad A. Yaghmour, ${ }^{1}$ Miin-Huey Lee,,2,3,4 Thomas M. Gradziel, ${ }^{5}$ Johan H. J. Leveau, \\ and Richard M. Bostock $1,3, \dagger$ \\ ${ }^{1}$ Department of Plant Pathology, University of California, Davis, CA, U.S.A. \\ 2 Department of Plant Pathology, National Chung Hsing University, Taichung, Taiwan R.O.C. \\ ${ }^{3}$ NCHU-UCD Plant and Food Biotechnology Center, National Chung Hsing University \\ ${ }^{4}$ Agricultural Biotechnology Center, National Chung Hsing University \\ ${ }^{5}$ Department of Plant Sciences, University of California, Davis, CA, U.S.A. \\ Accepted for publication 31 August 2019.
}

ABSTRACT

\begin{abstract}
The reduction-oxidation (redox) environment of the phytobiome (i.e., the plant-microbe interface) can strongly influence the outcome of the interaction between microbial pathogens, commensals, and their host. We describe a noninvasive method using a bacterial bioreporter that responds to reactive oxygen species and redox-active chemicals to compare microenvironments perceived by microbes during their initial encounter of the plant surface. A redox-sensitive variant of green fluorescent protein (roGFP2), responsive to changes in intracellular levels of reduced and oxidized glutathione, was expressed under the constitutive SP6 and fruR promoters in the epiphytic bacterium Pantoea eucalypti 299R (Pe299R/roGFP2). Analyses of Pe299R/roGFP2 cells by ratiometric fluorometry showed concentration-dependent responses to several redox active chemicals, including hydrogen peroxide $\left(\mathrm{H}_{2} \mathrm{O}_{2}\right)$, dithiothreitol (DTT), and menadione. Changes in intracellular redox were detected within 5 min of addition of the chemical to Pe299R/roGFP2
\end{abstract}

cells, with approximate detection limits of 25 and $6 \mu \mathrm{M}$ for oxidation by $\mathrm{H}_{2} \mathrm{O}_{2}$ and menadione, respectively, and $10 \mu \mathrm{M}$ for reduction by DTT. Caffeic acid, chlorogenic acid, and ascorbic acid mitigated the $\mathrm{H}_{2} \mathrm{O}_{2}$ induced oxidation of the roGFP2 bioreporter. Aqueous washes of peach and rose flower petals from young blossoms created a lower redox state in the roGFP2 bioreporter than washes from fully mature blossoms. The bioreporter also detected differences in surface washes from peach fruit at different stages of maturity and between wounded and nonwounded sites. The Pe299R/roGFP2 reporter rapidly assesses differences in redox microenvironments and provides a noninvasive tool that may complement traditional redox-sensitive chromophores and chemical analyses of cell extracts.

Keywords: biochemistry and cell biology, brown rot, caffeic acid, chlorogenic acid, Monilinia fructicola, techniques
Plant surfaces present a unique and challenging environment to microbial colonizers. Phytochemical studies indicate that surface chemistry varies considerably across different species and organs, is dynamic during development with spatiotemporal variation within a given organ, and can be determinative in the success or failure of commensals to colonize and pathogens to infect a host (Kolattukudy et al. 1995; Martin and Rose 2014; Podila et al. 1993; Ryffel et al. 2016; Vorholt 2012). Microbial pathogens encounter both promotive and inhibitory factors at the preinfection and initial penetration stages of the interaction. For example, inorganic and organic compounds may serve as essential nutrients or provide signals to promote germination and growth, trigger differentiation of infection structures, and regulate the expression of virulence and pathogenicity factors (Fatima and Senthil-Kumar 2015). Compounds such as iron and simple sugars are often limiting on plant

†Corresponding author: R. M. Bostock; rmbostock@ucdavis.edu

Current address of T.-H. Liu: Department of Power Mechanical Engineering, National Tsing Hua University, Room S17, Engineering Building I, No. 101, Section 2, Kuang-Fu Road, Hsinchu, Taiwan 30013, R.O.C.

Funding: T.-H. Liu was supported by the NCHU-UCD Plant and Food Biotechnology Center, a cooperative training program between the National Chung Hsing University (Taiwan) and the University of California, Davis, with funding provided by the Taiwan National Science Council. Research was also supported, in part, by funds from the University of California Agricultural Experiment station to R. M. Bostock.

*The $\boldsymbol{e}$-Xtra logo stands for "electronic extra" and indicates that five supplementary figures and three supplementary tables are published online.

The author(s) declare no conflict of interest.

(c) 2020 The American Phytopathological Society surfaces, and cellular pathogens have evolved efficient mechanisms for acquiring them (Haas et al. 2008; Loper and Buyer 1991; Mercier and Lindow 2000). Alternatively, a plethora of secondary metabolites may constrain pathogens, and surface polymers such as cutin, suberin, and lignin impede infection and ingress, all apparently contributing to the plant's preformed and basal defenses (Agrios 2005).

Fruit provide interesting and important models for investigating relationships between disease and host surface architecture and chemistry (Martin and Rose 2014). Chemical changes during fruit maturation together with modifications in cuticle integrity and subtending cell layers correspond with transitions from diseaseresistant to -susceptible states. For example, changes in proanthocyanidins and sugar composition contribute to the progressive increase in susceptibility to Botrytis cinerea in grape berries and strawberry (Jersch et al. 1989; Pezet et al. 2003). Citral, a fungitoxic terpene aldehyde in the pericarp of citrus fruit, declines during maturation of lemon fruit, and this decline may explain, in part, the higher susceptibility to Penicillium digitatum of mature fruit relative to younger fruit (Rodov et al. 1995). In the anthracnose disease of avocado caused by Colletotrichum gloeosporioides, levels of an antifungal diene are regulated by epicatechin and lipoxygenase. This compound contributes to pathogen arrest in quiescent infections in immature fruit and declines during fruit maturation (Prusky 1996). Antimicrobial triterpenoids such as ursolic and oleanic acids are abundant in the epicuticular waxes of many different fruit and often decline during fruit ripening (Pensec et al. 2014). Changes in fruit $\mathrm{pH}$ during ripening also may influence secretion of pathogenicity factors by fungal pathogens (Alkan et al. 2013; Prusky and Yakoby 2003). The ripening-induced changes in the levels of the chemicals described above also may affect the redox state of the fruit surface, directly through changes in their 
concentration in solution (Buchholz 2006; Kerstiens 1996), as well as through changes in the antioxidative properties of individual chemical species as $\mathrm{pH}$ affects their electrochemical redox potentials (Corduneanu et al. 2006).

In peach fruit (Prunus persica $\mathrm{L}$. Batsch), cuticle structure and exocarp chemistry are determining factors in resistance to brown rot disease caused by Monilinia spp. (Gradziel and Wang 1993; Gradziel et al. 1998; Lee and Bostock 2007). During fruit ripening, there is a thinning of the cuticle and fissuring of the surface corresponding to the transition from resistance to susceptibility to the pathogen. Levels of antioxidant catecholic phenols, particularly chlorogenic acid (CGA), neo-chlorogenic acids, caffeic acid (CA), epicatechin, and catechin, are very high in peach fruit peel and flesh at brown-rot-resistant stages but decline markedly as fruit approach the highly susceptible stage of harvest maturity (Andreotti et al. 2008; Biggs and Northover 1988; Kubota et al. 2000; Senter and Callahan 1990; Tomás-Barberán et al. 2001). We found that CGA and CA are not directly fungitoxic to Monilinia fructicola but, rather, these phenols and other antioxidants have a more subtle impact by inhibiting formation of appressoria and the expression of virulence factors (Bostock et al. 1999; Lee and Bostock 2007). Pharmacological experiments indicate that $M$. fructicola infection is a redox-sensitive process, implicating that a finely tuned balance in the levels of antioxidants and prooxidants contributes to regulate critical stages of this plant-microbe interaction (Chiu et al. 2013; Lee and Bostock 2006; Lee et al. 2010; Wang et al. 2002).

Changes in the levels of reactive oxygen species (ROS) can affect the expression of genes associated with growth and differentiation in fungi (Hansberg and Aguirre 1990). ROS are a byproduct of the aerobic metabolism of oxygen, and include superoxide radical $\left(\mathrm{O}_{2}{ }^{\bullet-}\right)$, hydroxyl radical $\left(\mathrm{OH}^{\prime}\right)$, and hydrogen peroxide $\left(\mathrm{H}_{2} \mathrm{O}_{2}\right)$. ROS's dual functions in causing cellular damage through oxidative stress and serving as second messengers in cell signaling are well established (Halliwell and Gutteridge 2015), and an oxidative stress response system as it affects fungal differentiation and pathogenicity has attracted increasing attention (Heller and Tudzynski 2011). In a clever example of fungal adaptation, the necrotroph $B$. cinerea not only escapes or alters the ROS generated by the plant but also produces ROS at the infection court to facilitate invasion by triggering programmed cell death (Heller and Tudzynski 2011). M. fructicola, a related member of the Sclerotiniaceae family and also a necrotroph, may actually perceive ROS to stimulate expression of cutinase MfCUT1, a virulence factor in the interaction (Chiu et al. 2013).

Although ROS levels provide an indicator of oxidative stress and associated signaling, they are only a partial measure of the microenvironment perceived by a cell that contributes to its intracellular redox state. The redox state, as defined by Yano et al. (2010), is a steady state determined by the total of redoxrelated metabolites produced from multiple pathways. The intracellular redox state, then, encompasses the physiological context established by the milieu of redox-related compounds, or redox pairs, that are at various electrochemical redox potentials. In spite of this complexity and acknowledging the limitations of using a specific redox pair as a proxy, cellular equilibrium redox states have been estimated by the ratio of reduced glutathione (GSH) and oxidized forms of glutathione such as glutathione disulfide (GSSG) (the GSH/GSSG ratio), because GSH is generally the primary intracellular antioxidant and important scavenger of ROS in eukaryotes and prokaryotes. However, chemical methods for determining the thiol/disulfide ratio are destructive and time consuming, and potentially subject to error due to losses of the target analytes.

Because of our interest in the chemical changes in the surface of fruit and other organs that may affect the redox state of pathogens, we sought a rapid, sensitive, and nondestructive method that captures the surface redox microenvironment on a scale relevant to microbial perception. Bioreporters have become important tools for chemosensing in microbial ecology and reveal that the chemical microenvironment engages a range of cellular processes, including signal transduction, gene expression, and metabolism in the epiphytic microflora (Leveau and Lindow 2002; Lindow and Brandl 2003). A number of reduction-oxidation (redox)-sensitive green fluorescent protein (roGFP) indicators have been developed as semiquantitative reagents for the study of cellular thiol/disulfide equilibria (Dooley et al. 2004; Lohman and Remington 2008).

Hanson et al. (2004) engineered cysteines into the positions S147 and Q247 of GFP and enhanced GFP to generate two roGFPs, roGFP1 and roGFP2, respectively. These roGFPs display two excitation maxima at approximately 390 to $400 \mathrm{~nm}$ and approximately 475 to $490 \mathrm{~nm}$, respectively, in fluorescence emission in response to the ambient thiol/disulfide ratio. Ratiometric fluorometry can be used to determine changes in the proportion of reduced and oxidized forms of the roGFP. roGFP constructs have been used to transform animal, plant, and fungal cells for in vivo imaging of redox states of the cytosol and subcellular compartments (Hanson et al. 2004; Heller et al. 2012; Meyer et al. 2007; Schwarzländer et al. 2008, 2009; Williams et al. 2011). roGFP2 is a particularly sensitive indicator that displays two-state changes in fluorescence emission in response to the ambient GSH/GSSG ratio, and provides a measure of the cellular glutathione redox potential (Meyer and Dick 2010). In an elegant study, roGFP2 was expressed in $B$. cinerea to assess reversible changes in the glutathione pool during growth and differentiation of hyphae and infection structures and in response to oxidants (Heller et al. 2012). The roGFP indicators have become important tools for noninvasive, reversible, and dynamic imaging of the associated thiol/disulfide equilibria (Dooley et al. 2004; Lohman and Remington 2008; Meyer and Dick 2010).

roGFP2 has also been expressed in bacteria, an example being Escherichia coli that can provide a semiquantitative biosensor for detecting toxins that cause cellular oxidation (Arias-Barreiro et al. 2010). In the present study, roGFP2 was cloned and expressed under strong constitutive promoters in the epiphytic bacterium Pantoea eucalypti 299R (Pe299R) (syn. P. agglomerans 299R, syn. Erwinia herbicola 299R) to create a single-cell biosensor to prospect redox microenvironments on plant surfaces. We selected Pe299R because of its successful use with various reporter constructs in microbial ecology studies (Leveau and Lindow 2001, 2002; RemusEmsermann and Leveau 2010; Tecon and Leveau 2012). The engineered Pe299R/roGFP2 was used as a surrogate for detecting redox differences in chemical microenvironments that pathogen propagules such as fungal conidia may encounter upon initial contact with the plant. In the format reported here, we used the roGFP2 bioreporter to compare small-volume aqueous washes ("diffusates") from peach and rose flower petals and from peach fruit surfaces at different stages of maturity, between wounded and nonwounded sites, and between peach fruit genotypes resistant and susceptible to M. fructicola. We also provide evidence that the more oxidized the host surface, as inferred by the bioreporter response to diffusates collected from that surface, the greater the lesion development by $M$. fructicola in the host. The method we describe offers a rapid and potentially high-throughput approach for evaluating differences in redox microenvironments in the phytobiome (i.e., the plant as a habitat for microbes) and provides a proof of concept that should be adaptable for studies in bacteria and fungi in other contexts.

\section{MATERIALS AND METHODS}

Bacterial strains and culture conditions. Cells of the wellcharacterized epiphytic bacterium Pe299R (Leveau and Lindow 2002) were transformed with the redox bioreporter plasmid pPROBE/pPfruR-roGFP2 (see below), which allows constitutive expression of the roGFP2. We chose roGFP2 over other roGFP variants because of its highly sensitive response to the ambient GSH/GSSG ratio in a cell (Meyer et al. 2007; Meyer and Dick 
2010). Kanamycin (50 mg liter ${ }^{-1}$ ) was used to ensure plasmid maintenance on Luria-Bertani (LB) agar and liquid media. Escherichia coli DH5 $\alpha$ (Invitrogen, Carlsbad, CA, U.S.A.) was used for routine cloning of plasmids and as a source for the fruR promoter (see below). Bacterial cultures were grown at $28^{\circ} \mathrm{C}$ (Pe299R) or $37^{\circ} \mathrm{C}(\mathrm{DH} 5 \alpha)$ in LB broth or on solid LB medium, where appropriate.

Plasmid construction and expression of roGFP2 in Pe299R. Our strategy involved the use of roGFP2 gene technology, in which the plasmid $\mathrm{pPROBE} / \mathrm{pP}_{\text {fruR }}$-roGFP2 was constructed as follows. As described previously (Tecon and Leveau 2012), a 1.3-kb DNA fragment containing the constitutive promoter of the fruR promoter $\left(\mathrm{P}_{\text {fruR }}\right)$ was amplified from the genomic DNA of DH5 $\alpha$ using modified primers $5^{\prime}$-GAATTCGATGCATTTTTAGCATCG-3' with an EcoRI restriction site (italics) and 5'-GGATCCGTTC GCGGCTTAGCTACG-3' with a BamHI restriction site (italics), then cloned into pGEM T-easy vector (Promega Corp., Madison, WI, U.S.A.). The $\mathrm{P}_{\text {fruR }}$ fragment was excised and cloned into the vector pPROBE-NT' (confers resistance to kanamycin) and designated $\mathrm{pPROBE} / \mathrm{P}_{\text {fruR }}$. The open reading frame (ORF) of roGFP2 encoding 238 amino acid residues (Hanson et al. 2004) was amplified by PCR from plasmid pRSET-roGFP2 (Dooley et al. 2004) with paired primers 5'-AGGCTCGAGCATATGAGTAAAG GAGAAG-3', adding an XhoI restriction site (underlined) and NdeI restriction site (italics), and $5^{\prime}$-AAGCTTTCATTATTTGTATAGTT CATCC-3', with an HindIII restriction site (italics). The PCR amplicon was used as a template for second-round PCR amplification with paired primers 5'-GGATCCAGGAGGCTCGAGCATATG-3', containing a BamHI recognition site (italics) and a ribosomal binding site sequence (underlined), and 5'-AAGCTTTCATTATTTG TATAGTTCATCC-3'. The PCR amplicon was then cloned into pGEM-T easy vector (Promega Corp.) and transformed into DH5 $\alpha$ competent cells. The fidelity of the cloned sequence was confirmed by DNA sequencing. After sequence confirmation, the roGFP2 sequence was excised with BamHI and HindIII, then cloned into BamHI/HindIII-digested pPROBE- $\mathrm{P}_{\text {fruR }}$ to generate pPROBE- $\mathrm{P}_{f r u R^{-}}$ roGFP2, which expresses roGFP2 constitutively from the $\mathrm{P}_{\text {fruR }}$ promoter. An unexpected clone (pPROBE-SP6-P fruR -roGFP2) containing the strong promoter SP6 from the pGEM T-easy vector upstream of the $\mathrm{P}_{f r u R}$ promoter was also obtained during antibiotic screening. The constructed plasmids $\mathrm{pPROBE}-\mathrm{P}_{\text {fruR }}$-roGFP2 and pPROBE-SP6-P fruR -roGFP2 were transformed into rifampicinresistant Pe299R to generate Pe299R(pPROBE-P fruR $_{\text {-roGFP2) and }}$

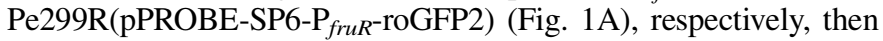
screened and cultured in LB agar and liquid media with kanamycin at $50 \mathrm{mg} \mathrm{liter}^{-1}$ and rifampicin at $100 \mathrm{mg} \mathrm{liter}^{-1}$ at $28^{\circ} \mathrm{C}$.

Microscopic and spectrophotometric characteristics of Pe299R expressing roGFP2. Pe299R(pPROBE- $\mathrm{P}_{\text {fruR }}$-roGFP2) and Pe299R(pPROBE-SP6- fruR $_{\text {-roGFP2) cells were cultured }}$ overnight at $28^{\circ} \mathrm{C}$ in LB medium with kanamycin and rifampicin. Cells were viewed with a Leica DM5000 B fluorescence microscope (Wetzlar, Germany). Fluorescent images were sequentially recorded using a monochrome camera at $\times 400$ magnification using a GFP filter cube (exciter: 470/40; emitter: 525/50; beam splitter: 495). The Pe299R(pPROBE-SP6-P fruR- $^{-}$ roGFP2) cells (herewith Pe299R/roGFP2) fluoresced more strongly than Pe299R(pPROBE- fruR $_{\text {-roGFP2) cells and, there- }}$ fore, the former strain was selected for use in the remainder of this study. For fluorescence spectrophotometry, $1 \mathrm{ml}$ of a Pe299R/ roGFP2 cell suspension from an overnight culture was transferred to $50 \mathrm{ml}$ of $\mathrm{LB}$ liquid medium containing kanamycin and rifampicin, and further cultivated at $28^{\circ} \mathrm{C}$ for $3 \mathrm{~h}$ to an optical density of 0.9 at $600 \mathrm{~nm}$. Note: we also compared 5-h cultures with 3-h cultures and found no difference in fluorometric response of the bioreporter cells. Cells were collected by centrifuging the $50-\mathrm{ml}$ suspension at 3,000 rpm for $5 \mathrm{~min}$ and washed twice in $5 \mathrm{mM}$ 4-(2-hydroxyethyl)-1-piperazine ethanesulfonic acid (HEPES) buffer containing $150 \mathrm{mM} \mathrm{NaCl}$ (pH 7.0).
The pelleted cells were resuspended in $10 \mathrm{ml}$ of the HEPES buffer for use in experiments.

Ratiometric fluorometry measurements of Pe299R/roGFP2 cell suspensions were obtained with a SpectraMax M2 Multi-Mode

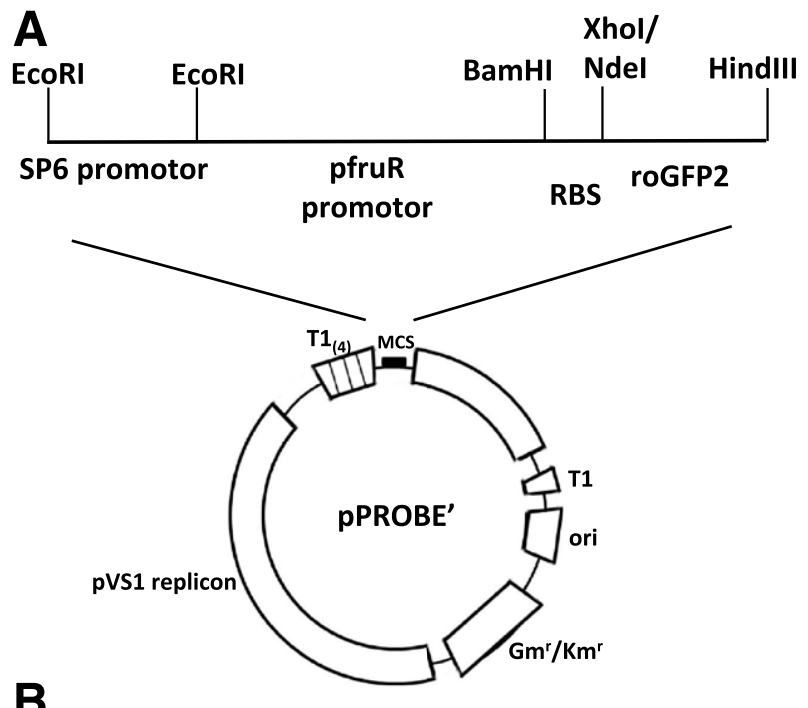

B

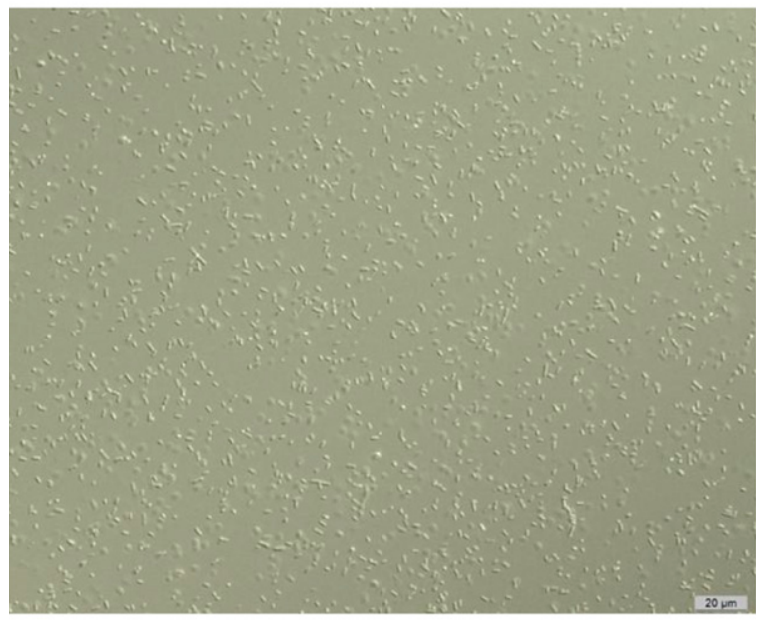

C

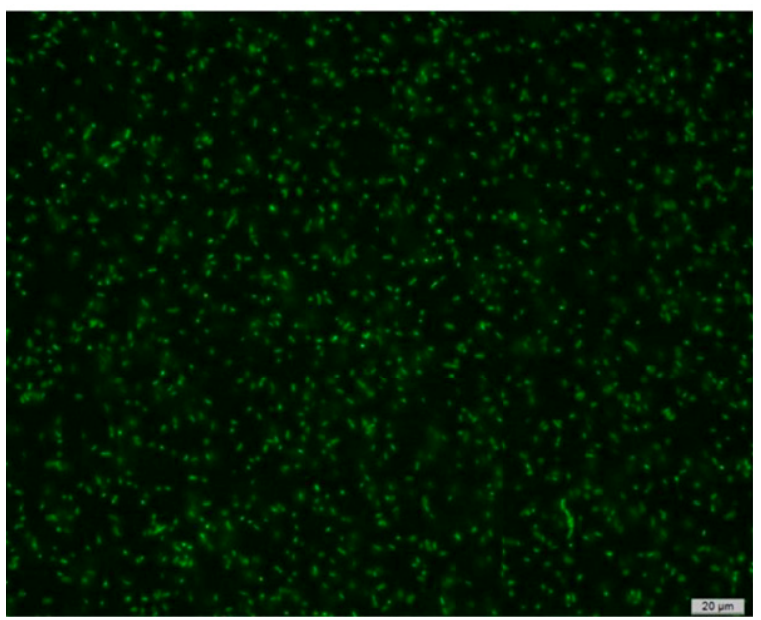

Fig. 1. Plasmid construction and overexpression of reduction-oxidation-sensitive green fluorescent protein 2 (roGFP2) in Pantoea eucalypti 299R (Pe299R). A, Construct design of pPROBE-SP6-PfruR-roGFP2. The plasmid contains two constitutive promotors, PfruR and SP6, and a ribosomal binding site (RBS). The accuracy of plasmid construction was confirmed by direct sequencing. Pe299R cells were transformed with plasmid pPROBE-SP6PfruR-roGFP2 to create Pe299R/roGFP2. Transformed cells as observed by $\mathbf{B}$, bright field and $\mathbf{C}$, fluorescence microscopy. 
Microplate Reader (Molecular Devices, Sunnyvale, CA, U.S.A.) using black 96-well flat bottom microplates (Corning Costar; Thermo Fisher Scientific, Waltham, MA, U.S.A.). Wavelengths were scanned from 370 to $490 \mathrm{~nm}$ to determine optimal excitation, with the emission wavelength fixed at $525 \mathrm{~nm}$. Bandwidths of excitation and emission were set at 3 and $10 \mathrm{~nm}$, respectively.

To test the effect of redox active chemicals on Pe299R/roGFP2 cells, aliquots $(98 \mu \mathrm{l})$ of cell suspension were placed in the wells of the black multiwell assay plates. A test chemical solution $(2 \mu \mathrm{l})$ was added to the wells, with mixing for $3 \mathrm{~s}$ just prior to the beginning of fluorescence measurements. The dual excitation-single emission behavior of roGFP2 cells was recorded for each time interval using excitation wavelengths of 390 and $480 \mathrm{~nm}$ and emission set at $525 \mathrm{~nm}$. roGFP2 fluorescence characteristics for cells at their initial state followed by a series of measurements after treatment with $20 \mathrm{mM} \mathrm{H}_{2} \mathrm{O}_{2}$ provided a time course for the Pe299R/roGPF2 cells to achieve the fully oxidized state. The ratio of the fluorescence values recorded at $525 \mathrm{~nm}$ following excitation at $390 \mathrm{~nm}$ and $480 \mathrm{~nm}$ $\left(\mathrm{F}_{\mathrm{ex}} 390 / \mathrm{F}_{\mathrm{ex}} 480 \mathrm{~nm}\right)$ (i.e., 390/480 ratio) was used as an index for cellular oxidation (Meyer et al. 2007). The higher this ratio, the more oxidizing the cellular environment; the lower this ratio, the more reducing the environment.

To determine whether CA (Sigma-Aldrich, St. Louis, MO, U.S.A.) affected oxidation of Pe299R/roGPF2 induced by $\mathrm{H}_{2} \mathrm{O}_{2}$, aliquots $(96 \mu \mathrm{l})$ of cells were mixed with $2 \mu \mathrm{l}$ of CA stock solutions to achieve final concentrations $0.5,1.0$, and $2.5 \mathrm{mM} \mathrm{CA}$; then, $2 \mu \mathrm{l}$ of $\mathrm{H}_{2} \mathrm{O}_{2}$ stock solution was added to achieve final concentrations of 1,5 , and $10 \mathrm{mM}$, with mixing for $3 \mathrm{~s}$. The 390/480 ratios for the treated cells were determined as described above. Ascorbic acid (Sigma-Aldrich) was tested in a similar manner, at final concentrations of $0.57,1.14$, and $2.27 \mathrm{mM}$ ascorbate and 1,5 , and $10 \mathrm{mM} \mathrm{H}_{2} \mathrm{O}_{2}$.

Comparison of roGFP bioreporter response with redox electrode and luminol measurements of antioxidant $-\mathrm{H}_{2} \mathrm{O}_{2}$ mixtures. The response of Pe299R/roGPF2 cells to the ascorbate-CA- $\mathrm{H}_{2} \mathrm{O}_{2}$ mixtures as described above was compared with redox measurements of these same mixtures using two standard assays. The first method determined the absolute electrochemical redox potential of the ascorbate- $\mathrm{H}_{2} \mathrm{O}_{2}$ or $\mathrm{CA}-\mathrm{H}_{2} \mathrm{O}_{2}$ mixes with a platinum $\mathrm{Ag}-\mathrm{AgCl}$ combination electrode with an Accumet XL150 meter (Thermo Fisher Scientific) (Lee and Bostock 2007). Zobell's solution (potassium ferro-ferricyanide solution; YSI, Inc. Yellow Springs, $\mathrm{OH}$, U.S.A.) was used for instrument standardization for redox potential measurements. The antioxidant and $\mathrm{H}_{2} \mathrm{O}_{2}$ solutions were mixed to achieve the indicated concentrations in the HEPES-NaCl buffer $(\mathrm{pH} \mathrm{7})$ at a final volume of $5 \mathrm{ml}$, and redox electrode measurements were taken within 15 min after mixing. Three trials were conducted.

The second method, the luminol assay, in the format used here relies on the horseradish peroxidase (Sigma-Aldrich) catalyzed oxidation of luminol (5-amino-2,3-dihydro-phthalazine-1,4-dione, MW 177; Sigma-Aldrich) in the presence of $\mathrm{H}_{2} \mathrm{O}_{2}$. The antioxidant$\mathrm{H}_{2} \mathrm{O}_{2}$ mixtures were prepared at the same concentrations above in the HEPES-NaCl buffer $(\mathrm{pH} 7)$. A mixture $(150 \mu \mathrm{l})$ containing horseradish peroxidase $(10 \mu \mathrm{g} / \mathrm{ml})$ and luminol $(17 \mu \mathrm{g} / \mathrm{ml})$ was added to each well of a 96-well polystyrene plate followed by the addition of $10 \mu \mathrm{l}$ of the test mixture, resulting in a 16-fold dilution of the mixture. Chemiluminescence was measured on a TriStar LB 941 luminometer (Berthold Technologies, Oak Ridge, TN, U.S.A.) set at 30 repeat measurements per well and an interval time between measurements of $1.5 \mathrm{~min}$. Two trials were conducted, with three technical replicates per test mixture in each trial.

Preparation of plant materials, disease assay, and redox state measurements of plant surfaces as perceived by Pe299R/roGFP2. Peach blossoms and fruit at different stages of maturity were collected from mature trees at the orchards of the University of California-Davis (UC Davis) Foundation Plant Services (FPS) and brought to the laboratory for analyses. Redox measurements with the Pe299R/roGFP2 reporter were made on the same day as collection of the materials from the field and conducted at room temperature. Flower petals and fruit were used without additional preparation or washing. Rose flowers also were analyzed on the same day as collection without additional preparation or washing. The general format for nondestructively measuring redox microenvironments on plants using the Pe299R/roGFP2 reporter is illustrated in Supplementary Figure 1.

Peach blossoms. Unblemished petals from blossoms at different developmental stages-pink bud, initial bloom, and full bloom-were gently detached from flowers with sterile forceps. For each replication within a maturity stage, three petals were selected at random as a sample group. A drop of sterile deionized water $(150 \mu \mathrm{l})$ was added to the adaxial surface of one of the petals and allowed to remain for 5 min to solubilize surface chemicals; then, the liquid was transferred with a pipette to the second petal to remain for $5 \mathrm{~min}$. This process was repeated with the third petal. The accumulated diffusate $(150 \mu \mathrm{l})$ from three petals was added to a bioreporter cell pellet from a Pe299R/roGFP2 cell suspension that had been prepared to the specifications described above. Specifically, these pellets were obtained by centrifuging a $150-\mu l$ aliquot of the final $10-\mathrm{ml}$ reporter cell suspension at $3,000 \times \mathrm{g}$ for $5 \mathrm{~min}$ to remove HEPES buffer. Each diffusate-Pe299R/roGFP2 mixture was maintained at room temperature for $5 \mathrm{~min}$; then, $100 \mu \mathrm{l}$ of the mixture was subjected to ratiometric fluorometry. Two separate trials were conducted, with six replicates per treatment within each trial. In each trial, Pe299R/roGFP cell pellets resuspended in deionized water served as mock-treated controls ( $n=6$ per trial), with the 390/480 values for each of the plant diffusate samples then expressed relative to the average 390/480 value for the mock controls within that trial ("390/480 relative to mock").

Peach fruit. A similar format was used to report the redox status of diffusates collected from the surfaces of unblemished peach fruit. Two cultivars, Loadel and Bolinha, at different maturities and with or without wounding, were used for these experiments. At harvest maturity, Loadel fruit are highly susceptible to brown rot caused by M. fructicola, whereas Bolinha fruit have a comparatively high level of resistance to this disease (Feliciano et al. 1987). Although Loadel is an earlier-maturing cultivar relative to Bolinha, there is sufficient within-tree variation with both cultivars that allowed us to select fruit of similar color and size representing comparable maturity for these cultivars during the course of sampling. Diffusates were collected from a nonwounded surface of a fruit and from a wound created in another section of the same fruit. Each wound was created with a razor blade to make a thin vertical incision through the exocarp approximately $5 \mathrm{~mm}$ into the depth of the mesocarp and approximately $1 \mathrm{~cm}$ in length. Surface diffusates were obtained by applying a 150- $\mu \mathrm{l}$ drop of sterile deionized water to the area of interest and directly on the incision in the case of the wound treatment. After $3 \mathrm{~min}$, diffusates were collected by gently pumping a pipette four to five times to mix the droplet before withdrawal of the water droplet, which was then used to resuspend Pe299R/ roGFP 2 cell pellets and incubated prior to ratiometric fluorometry, as described above. Surface diffusates were collected from four fruit of each cultivar at each sampling date (i.e., each 390/480 value is the mean and standard error of four diffusates).

Rose petals. Flower petals of different blossom stages from rose varieties maintained within the UC Davis FPS Rose Clean Stock program gardens were collected for redox analyses with the bioreporter. Flowers were collected from 21 hybrid Rosa varieties, including hybrid tea, climbing, Grandiflora, and Floribunda types. After preliminary analyses with the bioreporter, we selected five hybrid tea varieties for further study because we had used a hybrid tea variety in previous studies with M. fructicola (Chiu et al. 2013). Blossoms were selected at the bud, partially open, and fully open stages, and petals were removed in the same manner as described for peach flower petals. Diffusates were collected from the adaxial surfaces of flower petals of the three blossom maturity stages 
similarly to the peach petals, except sterile deionized water $(150 \mu \mathrm{l})$ was added to each petal and allowed to remain for 3 min to solubilize surface chemicals; then, the droplets from the three petals were combined by transferring with a pipette to a microfuge tube. The combined diffusates $(150 \mu \mathrm{l})$ were analyzed with the Pe299R/ roGFP2 reporter as described above for peach petals. Four trials were conducted, with three to six replicate samples per cultivar and petal stage within a trial.

Rose petal disease assay. An experiment was performed to assess the reaction of petals from partially or fully opened blossoms of four of the hybrid rose varieties to inoculation with $M$. fructicola (strain Mf13-81, aka MUK-1) (Lee and Bostock 2007). Plastic containers with covers (10 5/8 by $75 / 8$ by 3 3/4 in., Part \#195C; Pioneer Plastics, Dixon, KY, U.S.A.) and support grids were surface sterilized with $70 \%$ ethanol and dried; then, petals were placed in the container on top of the grid. A thin layer of water was added to the container below the grid to maintain high humidity. A conidial suspension was prepared from a 7- to 10-day-old culture of $M$. fructicola growing on V8-agar medium, and each petal was inoculated by applying a 5- $\mu$ l droplet containing 500 conidia. Lesion areas were determined at 48 and $72 \mathrm{~h}$ postinoculation.

Experimental design and analyses. Experiments (trials) were conducted at least twice, or as indicated, with internal sample replicates for each treatment. The general experimental design was a complete randomized design, although rose petals were segregated by genotype into plastic containers to conduct disease assays. Statistical analyses were performed using JMP Pro software (version 12.0; SAS Institute, Cary, NC, U.S.A.) and are described in more detail within the results along with any transformations of the data to better fit a normal distribution where possible.

\section{RESULTS}

Expression of roGFP2 in Pe299R. The strategy for overexpressing roGFP2 involved amplifying the entire ORF (717 bp) from pRSET-roGFP2 (Hanson et al. 2004) and subcloning this into the expression vector pPROBE-NT' downstream of the constitutive $P_{\text {fruR }}$ promoter. An unexpected construct with an extra SP6 promoter upstream of the $P_{\text {fruR }}$ promoter also was obtained and selected during the cloning and screening process (Fig. 1A). In both cases, transformed Pe299R cells constitutively produced roGFP2 and grew normally compared with the wild-type (nontransformed) cells. Furthermore, the cells with the dual SP6- $P_{f r u R}$ promoter produced a stronger fluorescent signal than those expressing roGFP2 from $\mathrm{P}_{\text {fruR }}$ only, as observed by fluorescence microscopy (Fig. 1C) and by spectrofluorometry (data not shown). Therefore,

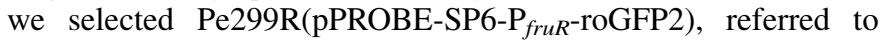
hereafter as Pe299R/roGFP2, for further characterization and then used it routinely in experiments.

Fluorometric characteristics of the Pe299R/roGFP2 bioreporter. To characterize the fluorescence characteristics of Pe299R/roGFP2 cells and optimize parameters for ratiometric analyses, cells were treated with various concentrations of $\mathrm{H}_{2} \mathrm{O}_{2}$, a strong oxidant, or dithiothreitol (DTT), a strong reductant, and their fluorescence measured with a SpectraMax M2 microplate reader (Fig. 2A and B). With the emission wavelength fixed at $525 \mathrm{~nm}$ and the excitation wavelength scanned from 370 to $490 \mathrm{~nm}$, we obtained an isosbestic point at $425 \mathrm{~nm}$. A fluorescence excitation ratio of $\mathrm{F}_{\mathrm{ex}} 390 \mathrm{~nm} / \mathrm{F}_{\mathrm{ex}} 480 \mathrm{~nm}$ (i.e., the $390 / 480 \mathrm{ratio}$ ) was selected to provide an index for cellular redox status, because we found that the ratio obtained with these excitation wavelengths provided the clearest differences in emission at $525 \mathrm{~nm}$ with the Pe299R/roGFP2 cells. Increased values of the 390/480 ratio correspond with oxidation of roGFP2 and decreased values with reduction of roGFP2.

Within 5 min following exposure of the Pe299R/roGFP2 cells to $\mathrm{H}_{2} \mathrm{O}_{2}$, we observed an increase of the 390/480 ratio over the range 0.01 to $20 \mathrm{mM} \mathrm{H}_{2} \mathrm{O}_{2}$, with the value reaching a plateau at $5 \mathrm{mM}$ (Fig.
3A). Similarly, menadione, a potent ROS-inducing agent assayed over the range 6 to $300 \mu \mathrm{M}$, also increased the ratio, with the curve reaching an asymptote at approximately $60 \mu \mathrm{M}$ (Fig. 3B). In contrast, the 390/480 ratios declined for Pe299R/roGFP2 cells exposed to the reductant DTT, assayed over the range from 0.01 to $20 \mathrm{mM}$, reaching a lower asymptote at approximately $10 \mathrm{mM}$ (Fig. $3 \mathrm{C})$. Higher concentrations $(50,100$, and $200 \mathrm{mM})$ of $\mathrm{H}_{2} \mathrm{O}_{2}$ and DTT were toxic to bioreporter cells, with consequent loss of fluorescence signals (data not shown). The linear range of the 390/ 480 response for the Pe299R/roGFP2 reporter under oxidizing conditions within our experimental format was 0 to $2.5 \mathrm{mM} \mathrm{H}_{2} \mathrm{O}_{2}$, defined by the regression equation 390/480 ratio $=0.0874\left(\mathrm{H}_{2} \mathrm{O}_{2}\right.$ $\mathrm{mM})+0.1271\left(R^{2}=0.99\right)$. The linear range of the $390 / 480$ response for the bioreporter under reducing conditions was 0 to $2.5 \mathrm{mMDTT}$, defined by the regression equation 390/480 ratio $=-0.0147$ (DTT $\mathrm{mM})+0.1272\left(R^{2}=0.92\right)$. The dynamic range $\left(\mathrm{R}_{\mathrm{ox}} / \mathrm{R}_{\mathrm{re}}\right)$ of Pe299R/ roGFP2 was 3.82, derived from the ratio of the 390/480 values calculated from the corresponding regressions with $2.5 \mathrm{mM} \mathrm{H}_{2} \mathrm{O}_{2}$ (full oxidation, $\mathrm{R}_{\mathrm{ox}}=0.3456$ ) and $2.5 \mathrm{mM} \mathrm{DTT}$ (full reduction, $\mathrm{R}_{\mathrm{re}}=$ 0.0904). The reporter was most sensitive under oxidizing conditions, providing a steeper slope of the concentration-response line with $\mathrm{H}_{2} \mathrm{O}_{2}$ than with DTT. The lowest observed effective concentrations to discriminate redox state changes of the bioreporter as discerned from the concentration-response curves were approximately $25 \mu \mathrm{M}$ for $\mathrm{H}_{2} \mathrm{O}_{2}, 6 \mu \mathrm{M}$ for menadione, and $10 \mu \mathrm{M}$ for DTT.
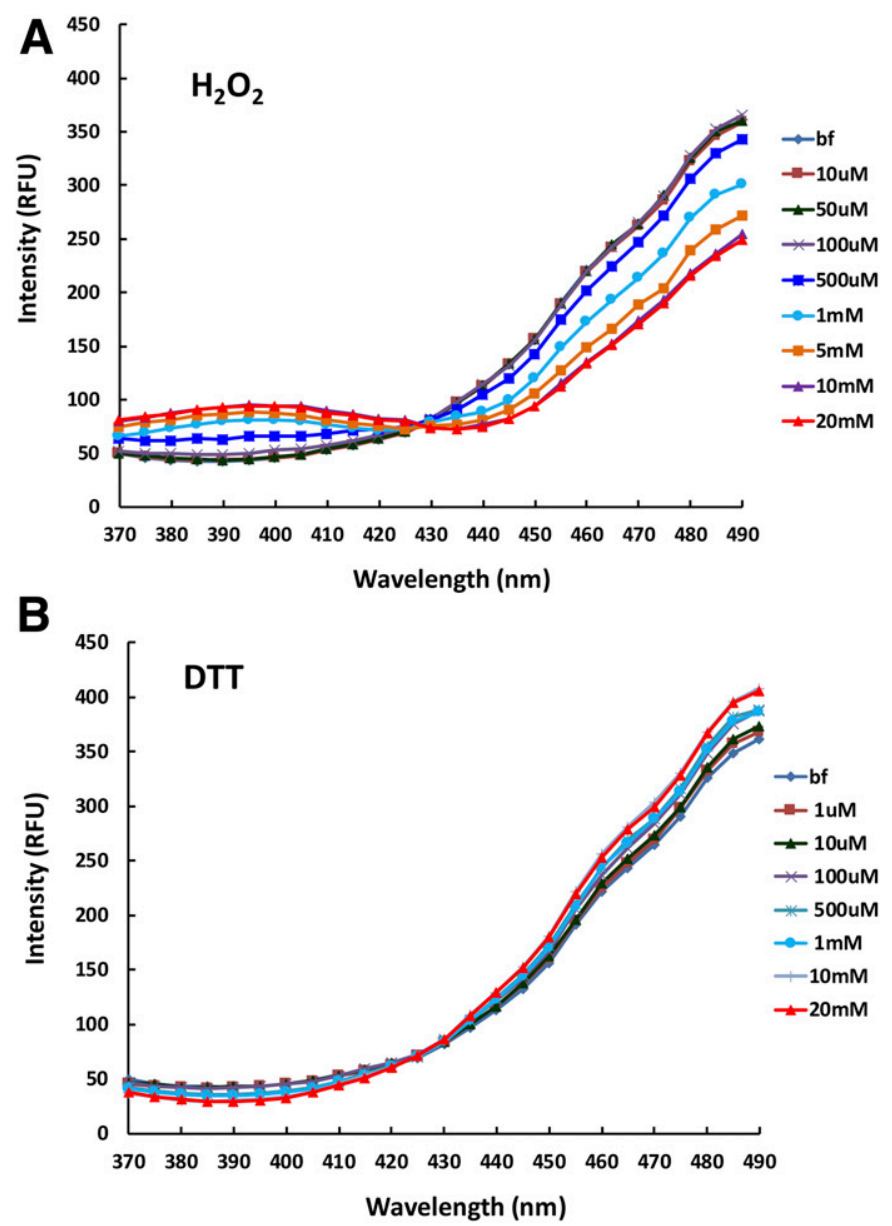

Fig. 2. Fluorometric characteristics of Pantoea eucalypti 299R reductionoxidation-sensitive green fluorescent protein 2 (Pe299R/roGFP2) cells treated with various concentrations of hydrogen peroxide $\left(\mathrm{H}_{2} \mathrm{O}_{2}\right)$ or dithiothreitol (DTT). Ratiometric fluorescence characteristics of Pe299R/roGFP2 cells treated for 5 min with $\mathbf{A}, \mathrm{H}_{2} \mathrm{O}_{2}$ or $\mathbf{B}$, DTT, as measured with a SpectraMax M2 microplate reader. Emission wavelength was fixed at $525 \mathrm{~nm}$ and excitation wavelength was scanned from 370 to $490 \mathrm{~nm}$. An isosbestic point is indicated at $425 \mathrm{~nm}$. 
Effect of CA and ascorbic acid on the Pe299R/roGFP2 bioreporter. CA and its quinate ester, CGA, are two abundant antioxidant phenolic compounds that decline during ripening in peach and tomato, both of which are hosts of important pathogens under study in our laboratories that prompted our interest in fruit surface redox chemistry (Bostock et al. 1999; Buta and Spaulding 1997). CA had little or no effect on the Pe299R/roGFP2 reporter values over the concentration range of 0.5 to $2.5 \mathrm{mM}$ (Fig. 4A; Supplementary Table S1). However, CA suppressed the $\mathrm{H}_{2} \mathrm{O}_{2}$ induced oxidation of the roGFP2 bioreporter in a concentrationdependent manner, as reflected in the 390/480 ratio, when the Pe299R/roGFP2 cells were treated simultaneously with the chemicals (Fig. 4B to D). At the final time point (500 s), the statistical significance at each of the $\mathrm{H}_{2} \mathrm{O}_{2}$ and $\mathrm{CA}$ concentrations
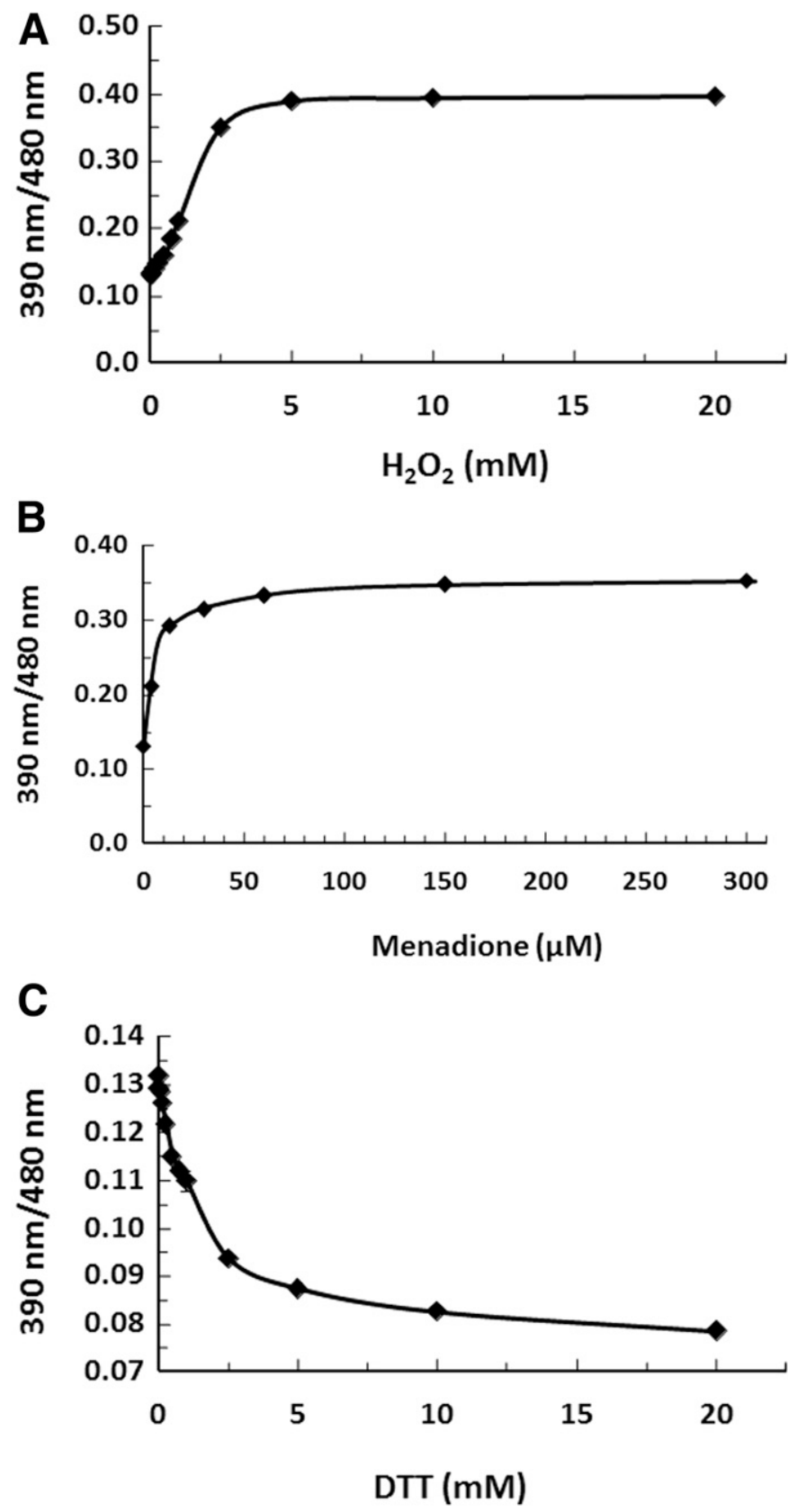

Fig. 3. Ratiometric analysis of Pantoea eucalypti 299R reduction-oxidationsensitive green fluorescent protein 2 (Pe299R/roGFP2) cells treated with various concentrations of $\mathbf{A}$, hydrogen peroxide $\left(\mathrm{H}_{2} \mathrm{O}_{2}\right) ; \mathbf{B}$, menadione; or $\mathbf{C}$, DTT. Readings were recorded using excitation at 390 and $480 \mathrm{~nm}$ and a 525$\mathrm{nm}$ emission filter. Oxidation increases and reduction decreases the 390/480 ratio. relative to the no CA control was determined and is summarized in Supplementary Table S1. Similar results were obtained with CGA (data not shown).

Ascorbic acid is also important in redox cycling and, with GSH, scavenges ROS in plants and other organisms (Foyer and Noctor 2011; Halliwell and Gutteridge 2015). Exogenous ascorbic acid when tested alone at three concentrations $(0.57,1.14$, and $2.27 \mathrm{mM})$ did not significantly alter the roGFP fluorescence response in Pe299R/roGFP2 cells relative to the control (Supplementary Fig. $\mathrm{S} 2 \mathrm{~A}$ ). However, similar to $\mathrm{CA}$, ascorbic acid buffered $\mathrm{H}_{2} \mathrm{O}_{2}$ 's oxidation of the bioreporter fluorescence signal over the concentration ranges tested (Supplementary Fig. S2B to D; Supplementary Table S2).

Comparison of the bioreporter response to redox electrode and luminol measurements of antioxidant $-\mathrm{H}_{2} \mathrm{O}_{2}$ mixtures. We compared measurements of the electrochemical redox potential and ROS in ascorbic acid-CA- $\mathrm{H}_{2} \mathrm{O}_{2}$ mixtures with the corresponding readouts obtained with Pe299R/roGFP2 cells. In a previous study, we used redox electrode measurements of the external medium to assess the influence of antioxidants on $M$. fructicola growth and behavior and cellular GSH/GSSG levels (Lee and Bostock 2007). For ROS measurements, the luminol assay provides a highly sensitive measure of $\mathrm{H}_{2} \mathrm{O}_{2}$, and reduction of peroxide-induced luminol chemiluminescence by antioxidants can be used as a measure of the antioxidant capacity in various biological fluids (Bastos et al. 2003). Although ascorbate and CA generally reduced peroxide-induced increases in oxidation state of the solutions as measured by the three assays, each assay displayed distinctive characteristics (Fig. 5). In the absence of an antioxidant, the roGFP bioreporter was very responsive to increasing concentrations of $\mathrm{H}_{2} \mathrm{O}_{2}$ (Fig. 5A and B). Over the range of concentrations tested, both ascorbate and CA reduced the 390/480 value within each peroxide concentration isoline, although never to a level of the peroxide-free $\left(0 \mathrm{mM} \mathrm{H} \mathrm{H}_{2} \mathrm{O}_{2}\right)$ values. The electrochemical redox potentials measured with a redox electrode responded similarly to the bioreporter readouts within the respective peroxide isolines, except in the case of the highest $\mathrm{CA}$ concentration $(2.5 \mathrm{mM})$. The reducing effect was more pronounced at the lower antioxidant concentrations but never achieved the levels of the peroxide-free control solutions (Fig. 5C and D). The impact of antioxidants on $\mathrm{H}_{2} \mathrm{O}_{2}$ levels was quite pronounced in the luminol assay, with ascorbate and $\mathrm{CA}$ reducing peroxide levels at all concentrations tested and, in some cases, equal to that of the peroxide-free control (Fig. 5E and D).

Surface redox measurements of different developmental stages of flower petals and fruit perceived by the Pe299R/ roGFP2 reporter. We tested the bioreporter with diffusates collected within a small droplet of water placed on flower petals and fruit. We found that different preparations of the bioreporter varied in their baseline 390/480 values in response to deionized water (mock; see Materials and Methods). To correct for any batch-tobatch variation with the Pe299R/roGFP2 cells, the values reported are the 390/480 ratios of diffusate-treated bioreporter relative to the $390 / 480$ signal for the bioreporter treated with deionized water within each experiment.

Peach blossoms. The blossom blight phase is a very important part of the disease cycle for brown rot in stone fruit. To determine whether the Pe299R/roGFP2 reporter can discern differences among developmental stages in peach flower petals (Loadel), petals were removed from detached blossoms at the bud and partially and fully open stages (Fig. 6A). We found the diffusates from petals of fully open blossoms to induce a significantly more oxidizing fluorometric signal from the bioreporter than the diffusates of younger-stage petals (Fig. 6B).

Peach fruit. To determine whether the Pe299R/roGFP2 reporter can discern differences in diffusates from surfaces of peach fruit of different maturities, fruit from two cultivars (Loadel and Bolinha) were collected during the course of the 2013 season beginning in mid-June (green, immature fruit; stage I), continuing during the 
pit-hardening phase (fruit of intermediate maturity; stage II), and ending in August at harvest maturity (stage III) (Zucconi 1986). Bolinha, a South American cultivar, also displays a high level of brown rot resistance relative to Loadel and other cultivars used in commercial production in California (Feliciano et al. 1987; Gradziel and Wang 1993) (Supplementary Fig. S3). Note: Some investigators further distinguish what we call third-stage fruit into stage III and stage IV (Guidarelli et al. 2014).

Diffusates from combined nonwounded stage II fruit (July samples) gave significantly lower relative 390/480 values than diffusates from fruit at stage I (June samples) or stage III (August samples) $(F=6.12, P=0.004)$ (Fig. 7A; Table 1). Diffusates from wounded surfaces of stage II fruit gave lower bioreporter redox values than diffusates from wounded stage III fruit $(F=3.31, P=$ 0.044) (Table 1). For both genotypes and over the course of sampling, diffusates collected from wounded fruit surfaces tended to elicit a lower redox reading with the bioreporter than diffusates from nonwounded surfaces (nonwounded $=1.100 \pm 0.015$, wounded $=1.055 \pm 0.018$; mean \pm standard error, $n=56 ; F=$ 3.92, $P=0.0501$ ). However, the bioreporter did not detect differences between Loadel and Bolinha fruit surfaces; the relative $390 / 480$ values of their surface diffusates were essentially the same within each fruit stage and sampling date and between nonwounded and wounded treatments for the two cultivars (Fig. 7B and C).
Several comparisons did not reach the significance threshold of $P<$ 0.05 , although they were significant at $P<0.10$ (Table 1 ).

Rose petals. We have used rose flower petals as a surrogate host in experimental studies with $M$. fructicola because genotypes vary in susceptibility to the pathogen, and rose blossoms are more readily available during the year than stone fruit blossoms (Chiu et al. 2013). To see whether Pe299R/roGFP2 cells can discern differences in diffusates from surfaces of flower petals, blossoms of different maturities were collected, ranging from immature buds to partially open and fully open blossoms (Supplementary Fig. S4). Of the 21 varieties for which we obtained preliminary results, we selected five hybrid tea varieties-Eclipse, Peace, Chicago Peace, Queen Mary, and Frau Karl Druschki-for disease evaluations and replicated redox trials. The 390/480 relative to mock values were log transformed to convert the data to fit a normal distribution, then analyzed using a mixed-model procedure. Within the individual rose varieties, only Queen Mary diffusates were significantly different among flower stages, with diffusates from petals of partially open blossoms having a lower redox value than diffusates from petals of buds or fully open blossoms (Supplementary Table S3). Diffusates from fully open blossom petals of Chicago Peace, although not reaching the significance threshold of $P<0.05$, were different from diffusates of the other petal stages at $P<0.10$. However, across the five varieties, there was a significant effect of
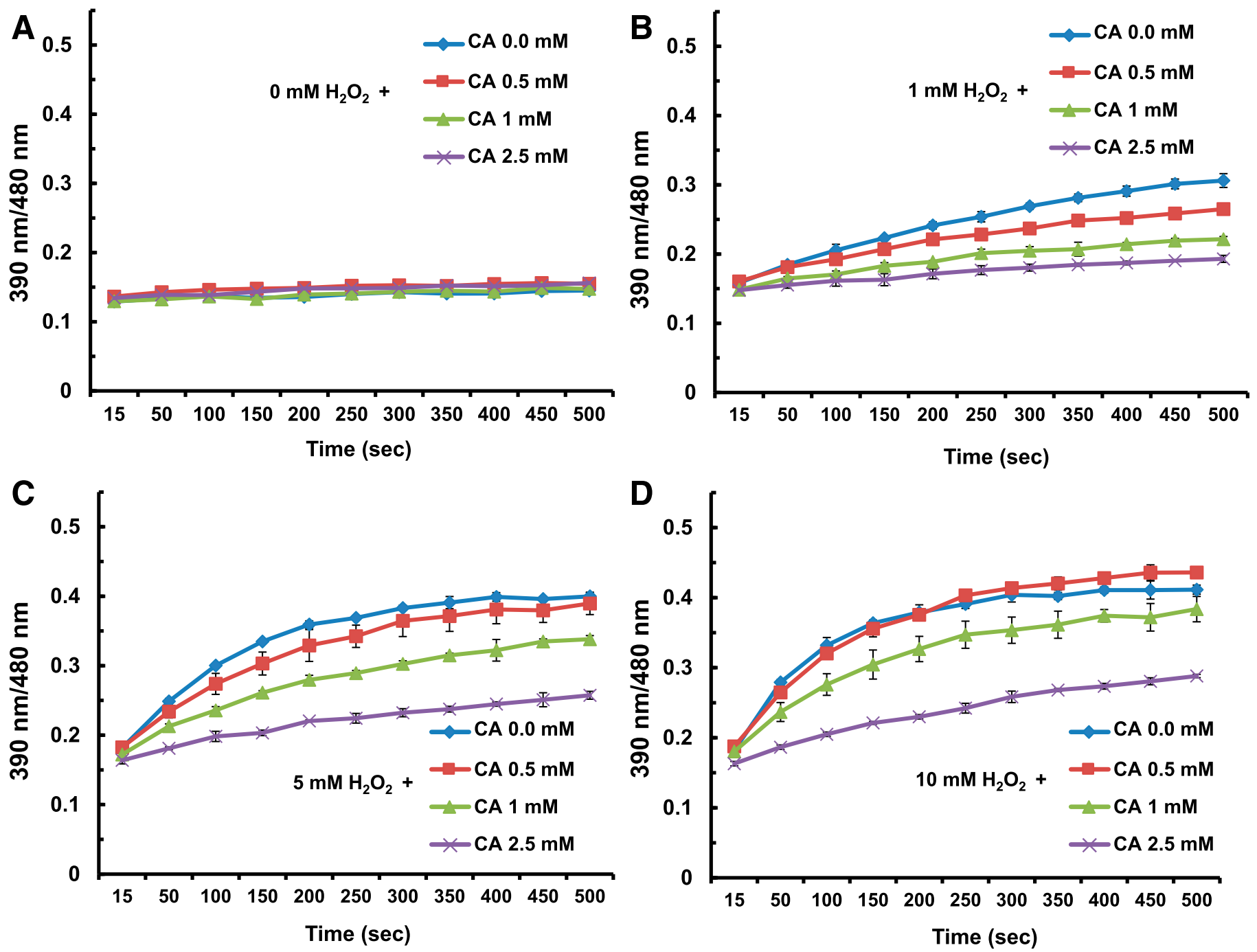

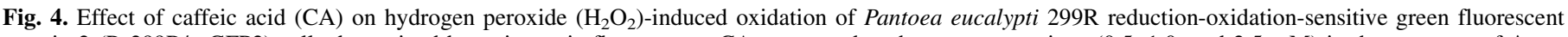

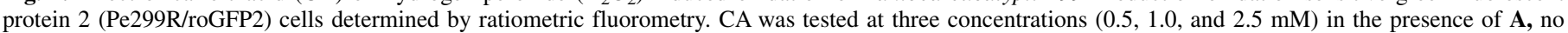

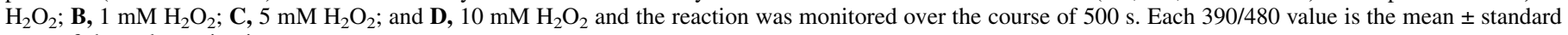
error of three determinations. 
flower stage $(F=3.454, P=0.033)$, with diffusates from petals of fully open blossoms having a significantly higher 390/480 value than petals from partially open blossoms. Diffusates from bud petals across the five varieties registered an intermediate 390/480 value that was not significantly different from the values obtained with the other blossom stages.

Petals from partially open and fully open blossoms for four of the five varieties were compared for their disease responses to M. fructicola and for their composite 390/480 values for these blossom stages. Although the differences among these varieties were subtle, one variety, Queen Mary, had the most oxidizing preinoculation roGFP2 value and the largest lesions (Table 2; Supplementary Fig. S5). When the data for the four varieties were pooled and compared with respect to blossom stage, lesion development and 390/480 values were significantly different between the two stages. Petals from fully open blossoms yielded more oxidizing diffusates and had larger lesions than petals from partially open blossoms (Table 3).

\section{DISCUSSION}

The redox bioreporter that we describe here represents a novel research tool that opens up experimental exploration of an underappreciated aspect of the phytobiome; namely, the redox environment. This roGFP-based bioreporter is a good example of what is currently possible in terms of bio-based redox sensing
A

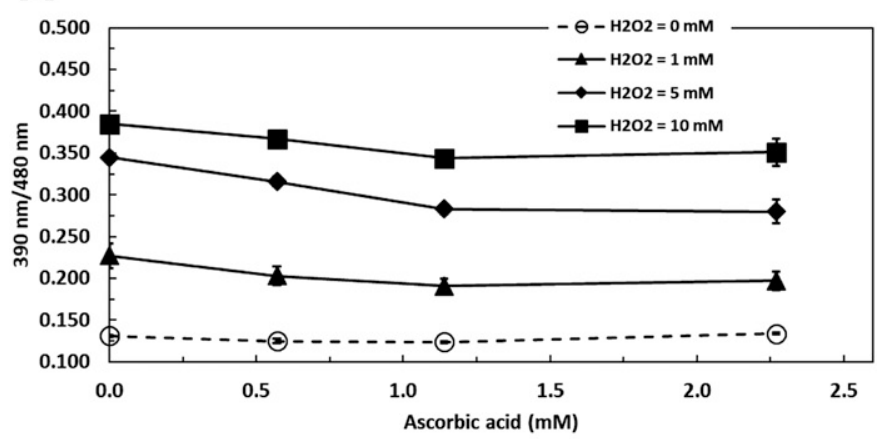

C

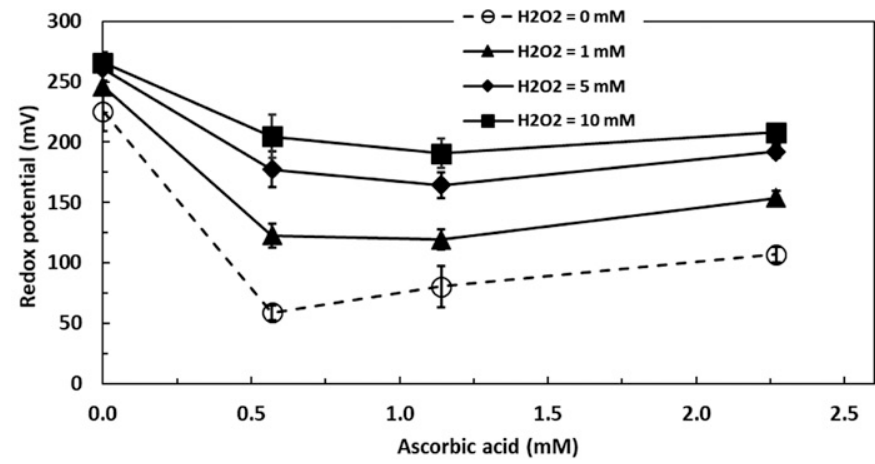

$\mathbf{E}$

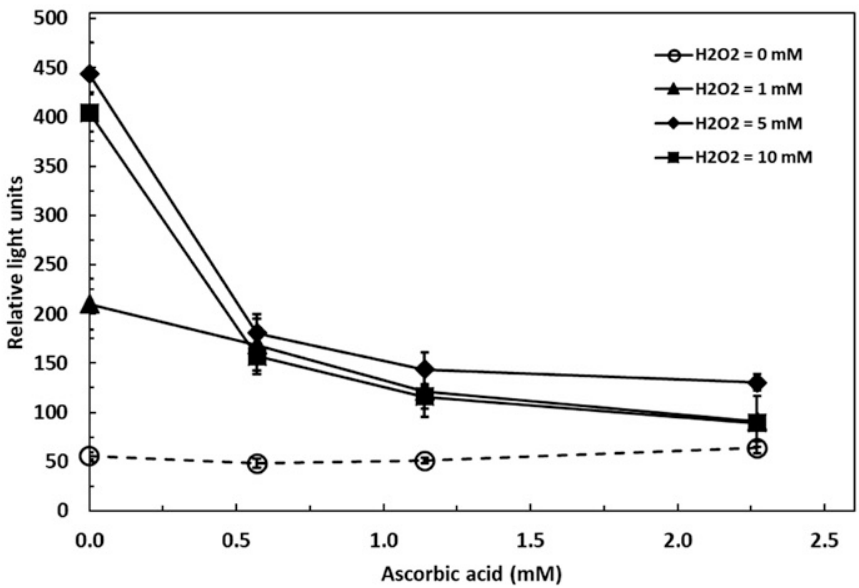

B

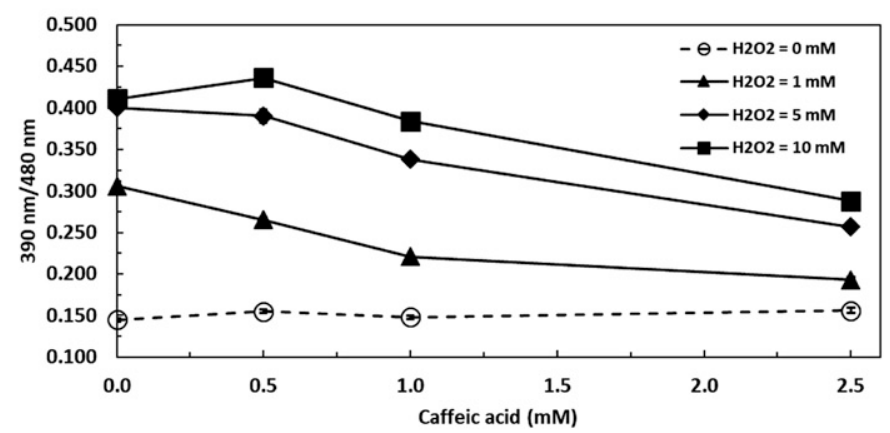

D

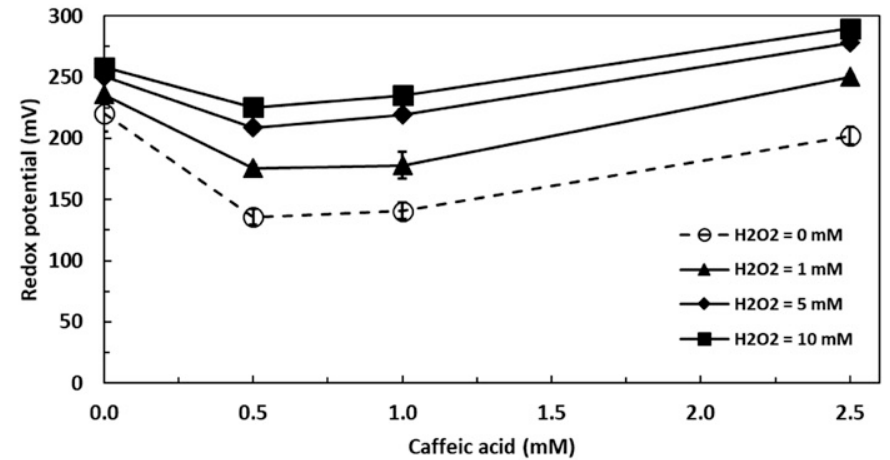

$\mathbf{F}$

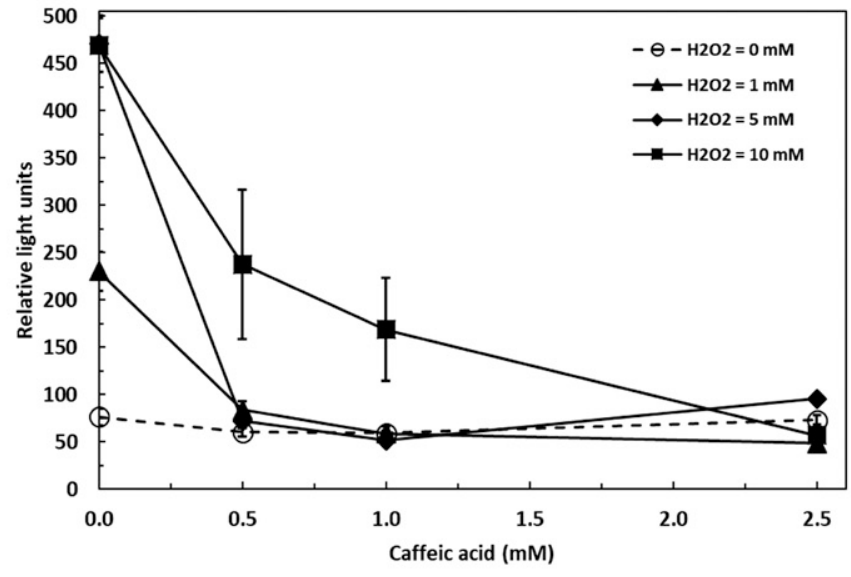

Fig. 5. Comparison of the bioreporter response to reduction-oxidation (redox) electrode and luminol measurements of antioxidant-hydrogen peroxide ( $\mathrm{H}_{2} \mathrm{O}_{2}$ ) mixtures. Redox measurements of solutions with varying concentrations of $\mathbf{A}, \mathbf{C}$, and $\mathbf{E}$, ascorbic acid, $\mathbf{B}, \mathbf{D}$, and $\mathbf{F}$, caffeic acid, and $\mathrm{H}_{2} \mathrm{O}_{2}$. $\mathbf{A}$ and $\mathbf{B}, \mathrm{Ratiometric}$ fluorescence response of Pantoea eucalypti 299R reduction-oxidation-sensitive green fluorescent protein 2 (Pe299R/roGFP2) cells at 500 s; C and D, electrochemical redox potentials determined with a redox electrode; and $\mathbf{E}$ and $\mathbf{F}$, luminol chemiluminescence determined with a luminometer. Legends for each $\mathrm{H}_{2} \mathrm{O}_{2}$ concentration isoline are presented within each panel. Each value is the mean \pm standard error (SE) of at least three determinations (A to D) or of six determinations (E and F) from two experiments. Statistical analyses of the data in A and B are presented in Supplementary Tables 1 and 2. Note: In many cases, the SE bars do not exceed the dimensions of the markers. 
capabilities and in terms of interrogating microbes about their single-cell experience of their surroundings as these pertain to redox status. In this study, we framed the utility of the bioreporter in the context of a fungal pathogen of floral and fruit tissue, building upon our previous studies that underscore the influence of the redox microenvironment on the pathogen's ability to establish and cause disease. However, the bioreporter's range of applications goes beyond fungi, pathogens, and even the plant surfaces examined here.

In this study, we successfully expressed roGFP2 within the epiphytic bacterium Pe299R under the control of two constitutive promoters. The fluorometric characteristics of Pe299R/roGFP2 cells include an isosbestic point and dynamic range that are similar and consistent with the literature regarding the behavior of roGFP2 (Hanson et al. 2004). This bioreporter responded to both strong oxidants and reductants but appears to be more responsive under oxidizing conditions, as shown by the steeper slope of the regression line for the concentration-response with $\mathrm{H}_{2} \mathrm{O}_{2}$ than with DTT. Although both luminol and bioreporter assays captured differences in $\mathrm{H}_{2} \mathrm{O}_{2}$ concentrations in the absence of antioxidants, the luminol assay was more responsive to the buffering of ROS levels by ascorbate and CA (Fig. 5A to D). However, it is important to emphasize that the Pe299R/roGFP2 as used in our experiments is
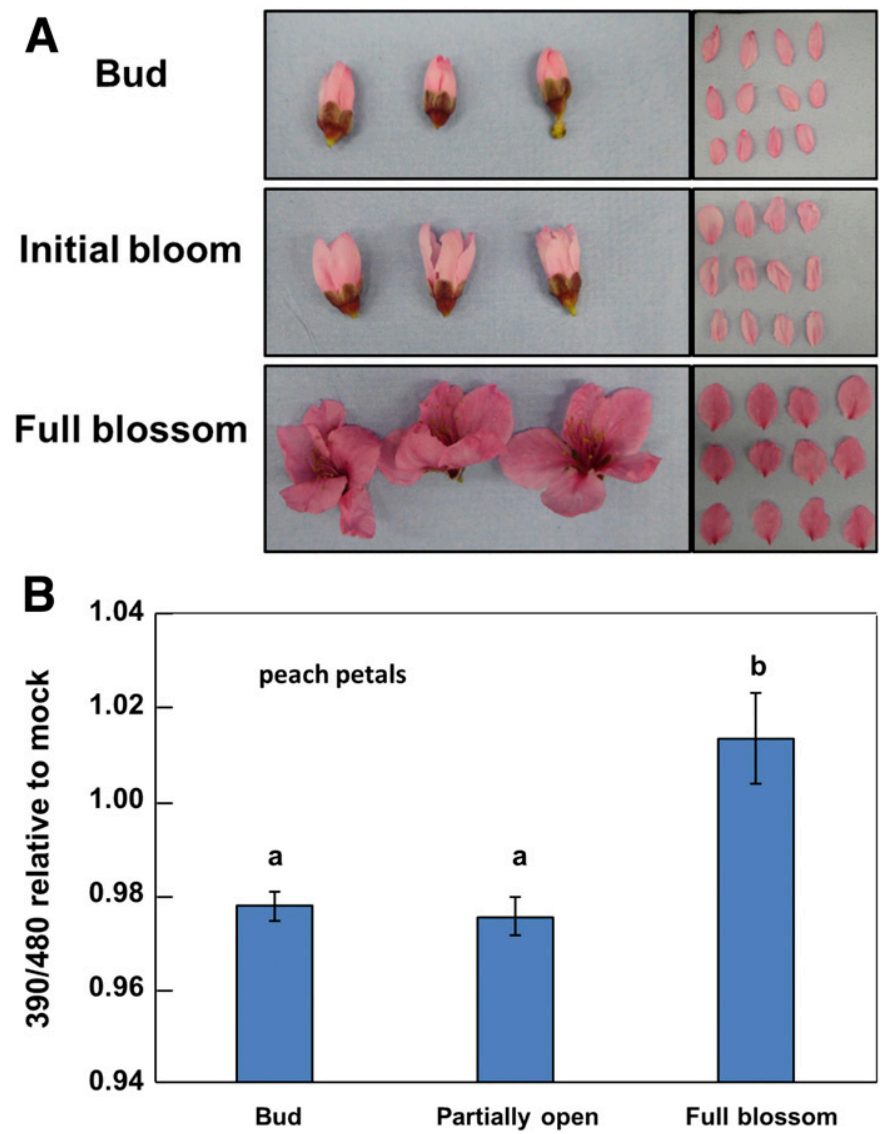

Fig. 6. Reduction-oxidation (redox) of aqueous diffusates from the surface of peach flower petals of different developmental stages as perceived by the Pantoea eucalypti 299R reduction-oxidation-sensitive green fluorescent protein 2 (Pe299R/roGFP2) bioreporter. A, Representative Loadel peach flowers of different developmental stages that were collected and their petals detached for use in experiments. B, Redox values of the diffusates from the petal surfaces estimated with the Pe299R/roGFP2 bioreporter. Each "390/480 relative to mock" value is the mean \pm standard error of 12 samples from two experiments. Values for treatment means for petal stage with the same letter are not significantly different by the Wilcoxon multiple comparisons test as performed in JMP Pro (version 12.0). Stage III versus stage $\mathrm{I}, \mathrm{Z}=3.26, P=0.001$; stage III versus stage II, $\mathrm{Z}=2.86, P=0.004$. not a measure of $\mathrm{H}_{2} \mathrm{O}_{2}$ or other specific ROS, per se. Various enhanced luminescent- and fluorescent-based detection assays such as the luminol assay used in this study have greater sensitivities, by an order of magnitude or more, for $\mathrm{H}_{2} \mathrm{O}_{2}$, for example (Díaz et al.
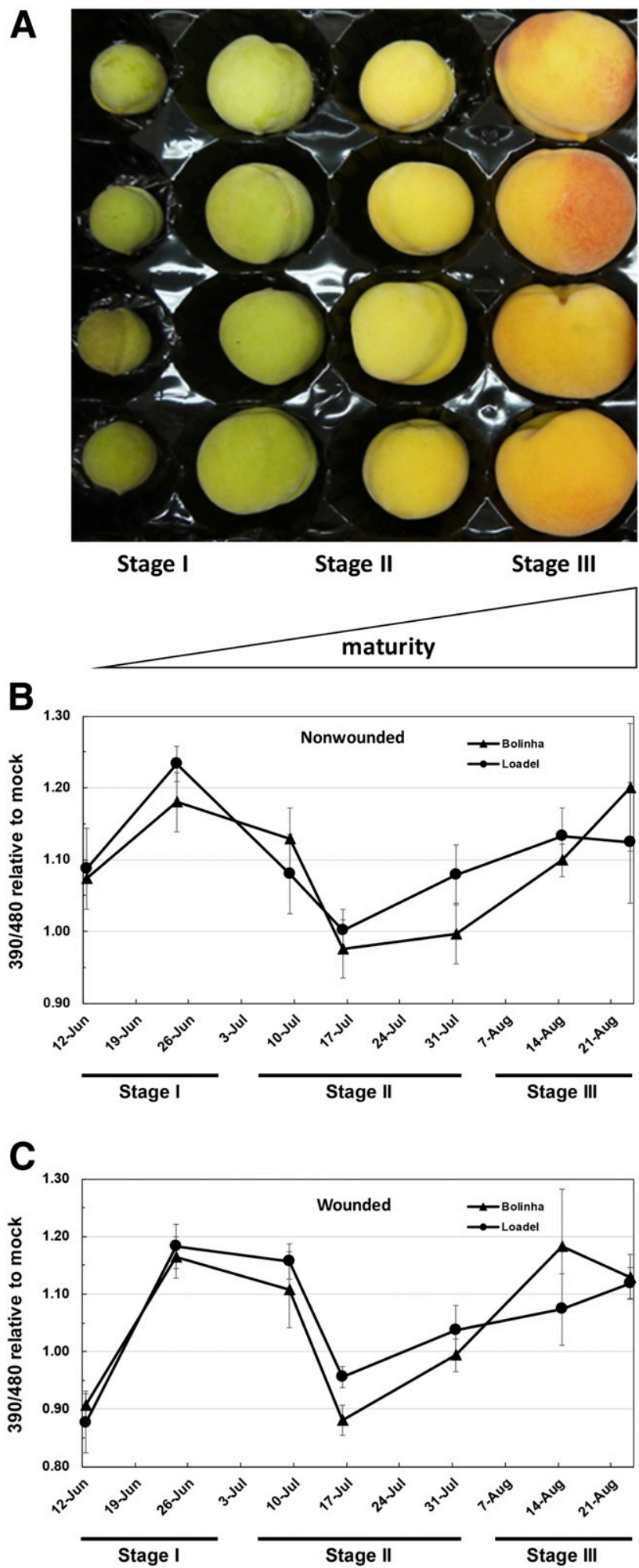

Fig. 7. Reduction-oxidation (redox) of aqueous diffusates from peach fruit surfaces of different developmental stages as perceived by the Pantoea eucalypti 299R reduction-oxidation-sensitive green fluorescent protein 2 (Pe299R/roGFP2) bioreporter. A, Representative fruit stages of Loadel peach fruit of increasing maturity. B, Values of 390/480 relative to mock for diffusates from the surfaces of nonwounded Bolinha and Loadel peach fruit. C, Values of 390/480 relative to mock for diffusates collected from wounds in Bolinha and Loadel peach fruit surfaces. Each value is the mean \pm standard error of four replicate samples. 
1996). Rather, the purpose of the bioreporter is to estimate the redox microenvironment created by the milieu of redox-active compounds as perceived by a microbial cell.

The Pe299R/roGFP2 reporter provided a sensor to estimate how aqueous washes from plant surfaces affect microbial cellular redox status as reflected in the GSH/GSSG equilibrium. Within this format, the 390/480 fluorescence ratio of the Pe299R/roGFP2 cells generally reached equilibrium (i.e., saturation) within $5 \mathrm{~min}$ (300 s) for the tested chemicals and plant diffusates (Figs. 2, 3 and 4). As such, the bioreporter provides a relatively rapid readout, a feature that would appeal to investigations requiring high-throughput, noninvasive approaches for prospecting redox microenvironments in other contexts.

What is striking in the present study is the apparent correspondence of the Pe299R/roGFP2 results with prior work that underscores the redox model we have proposed concerning Monilinia infection and virulence (Bostock et al. 1999; Lee and Bostock 2007; Yu et al. 2017). In this model, we hypothesize that, in the presence of phenolic antioxidants and a reducing environment, infections are arrested due to inhibition of the expression of factors and structures necessary for host penetration and invasion such as appressoria, cutinase, and other cell-wall-degrading enzymes (Bostock et al. 1999; Lee and Bostock 2006, 2007). In an oxidizing environment conditioned, in part, by elevated levels of ROS and reduced levels of phenolic antioxidants, $M$. fructicola infections are activated through stimulation of pathogenicity and virulence functions, provided ROS levels do not exceed a damaging threshold for the pathogen (Chiu et al. 2013; Lee et al. 2010). Previous studies have shown that stage I and stage III peach fruit are most susceptible to brown rot; however, as fruit transition through stage II, they are quite resistant and have a higher level of antioxidant catecholic phenols than at stages I and III (Andreotti et al. 2008; Biggs and Northover 1988; Gradziel et al. 1998; Ibbotson-Darhower et al. 1998; Kubota et al. 2000; Lee and Bostock 2007; Senter and Callahan 1990). Infections during stage II, when they occur, generally remain restricted and quiescent. In addition, the phenolic content of peach fruit corresponds well with the antioxidant activity

TABLE 1. Ratiometric fluorometry values for diffusates from Loadel and Bolinha peach fruit surfaces by stage of maturity and wound treatment as determined with the Pantoea eucalypti 299R reduction-oxidation-sensitive green fluorescent protein 2 (Pe299R/roGFP2) reporter

\begin{tabular}{|c|c|c|c|c|c|c|}
\hline \multirow[b]{3}{*}{ Stage $^{\mathrm{z}}$} & \multicolumn{6}{|c|}{$390 / 480$ ratio relative to mock $^{\mathrm{w}}$} \\
\hline & \multicolumn{2}{|c|}{ Loadel $^{\mathrm{x}}$} & \multicolumn{2}{|c|}{ Bolinha $^{\mathrm{x}}$} & \multicolumn{2}{|c|}{ Combined (Loadel + Bolinha)y } \\
\hline & $\mathrm{N}$ & $\mathrm{W}$ & $\mathrm{N}$ & $\mathrm{W}$ & $\mathrm{N}$ & $\mathrm{W}$ \\
\hline II & $1.054 \pm 0.025 \mathrm{a}^{*}$ & $1.050 \pm 0.030 \mathrm{a}$ & $1.034 \pm 0.030 \mathrm{a}^{*}$ & $0.994 \pm 0.036 \mathrm{~b}$ & $1.044 \pm 0.020 \mathrm{~b}$ & $1.022 \pm 0.024 \mathrm{~b}$ \\
\hline III & $1.128 \pm 0.043 \mathrm{a}$ & $1.096 \pm 0.033 \mathrm{a}$ & $1.150 \pm 0.047 \mathrm{a}$ & $1.156 \pm 0.051 \mathrm{a}$ & $1.139 \pm 0.031 \mathrm{a}$ & $1.126 \pm 0.030 \mathrm{a}$ \\
\hline
\end{tabular}

${ }^{w}$ Diffusates were collected from nonwounded $(\mathrm{N})$ and wounded $(\mathrm{W})$ fruit surfaces, as described in Materials and Methods. Values within a column followed by the same letter are not significantly different by Tukey's honestly significant difference for all pairwise comparisons at $P \leq 0.05$ using the Mixed Models personality within the Fit Model procedure in JMP Pro 12.0. Values followed by an asterisk $\left(^{*}\right)$ are different from the other values in that column at a threshold of $P<0.10$.

x Ratiometric fluorometry values for plant samples are expressed relative to the mock control (i.e., the ratiometric value obtained with water-treated Pe299R/ roGFP2 cells). Each value is the mean and standard error (SE) of 8 (stages I and III) or 12 (stage II) samples from two trials.

${ }^{y}$ Each value is the mean and SE of 16 (stages I and III) or 24 (stage II) samples from two trials.

${ }^{\mathrm{z}}$ Stage I fruit readings are the pooled June sample data, stage II fruit readings are the pooled July sample data, and stage III fruit readings are the pooled August sample data.

TABLE 2. Monilinia fructicola lesion sizes and ratiometric fluorometry values of diffusates on petals of partially and fully open blossoms from four rose varieties, listed in order of increasing oxidation effect of the diffusates on Pantoea eucalypti 299R reduction-oxidation-sensitive green fluorescent protein 2

\begin{tabular}{lcccc}
\hline Rose variety & Lesion area $(48$ hpi) & Incidence $^{\mathrm{x}}$ & ${\text { Lesion area } \times \text { incidence }^{\mathrm{y}}}^{\text {390/480 ratio relative to mock }}$ \\
\hline Peace & $10.1 \pm 1.2 \mathrm{a}(N=21)$ & 0.22 & 2.21 & $0.893 \pm 0.029 \mathrm{a}$ \\
Eclipse & $12.2 \pm 1.9 \mathrm{a}(N=22)$ & 0.23 & 2.80 & $0.902 \pm 0.045 \mathrm{a}$ \\
Frau Karl Druschki & $7.9 \pm 0.5 \mathrm{a}(N=34)$ & 0.35 & 2.80 & $0.930 \pm 0.014 \mathrm{a}, \mathrm{b}$ \\
Queen Mary & $17.0 \pm 1.3 \mathrm{~b}(N=32)$ & 0.33 & 5.67 & $0.983 \pm 0.023 \mathrm{~b}$ \\
\hline
\end{tabular}

${ }^{\mathrm{w}}$ Lesion area in square millimeters determined at $48 \mathrm{~h}$ postinoculation (hpi). Each value is the mean \pm standard error (SE) of $N$ lesions from 96 inoculation sites distributed over 16 petals (petals from 8 partially open and 8 fully open blossoms). Mean lesion areas do not include " 0 " values, where no lesion developed at an inoculation site. Within-column values followed by the same letter are not significantly different using mixed model and Tukey's honestly significant difference (HSD) all pairwise comparisons analyses within JMP Pro $12.0(P<0.05)$. Lesion area values were transformed to the predicted lesion radius to better fit a normal distribution prior to analysis.

x Proportion of sites with lesions out of 96 inoculated sites for each variety.

y Disease severity expressed as the product of average lesion area $x$ incidence for each variety.

${ }^{\mathrm{z}}$ Each value is the mean \pm SE of 30 samples from four trials, using the same data set as Supplementary Table S3, except combining the values for partially open and fully open blossoms and computing the average. Within-column values followed by the same letter are not significantly different using mixed model and Tukey's HSD all pairwise comparisons analyses within JMP Pro 12.0 on the log-transformed 390/480 relative to mock values $(P<0.05)$

TABLE 3. Influence of flower stage on Monilinia fructicola lesion sizes and ratiometric fluorometry values of diffusates on rose petals across four cultivars

\begin{tabular}{lrrr}
\hline & \multicolumn{2}{c}{ Lesion area $^{\mathrm{y}}$} \\
\cline { 2 - 3 } Flower stage & \multicolumn{1}{c}{$48 \mathrm{hpi}$} & $72 \mathrm{hpi}$ & $390 / 480$ relative to mock $^{\mathrm{z}}$ \\
\hline Partially open & $8.0 \pm 0.6 \mathrm{a}$ & $41.8 \pm 2.9 \mathrm{a}$ & $0.897 \pm 0.021 \mathrm{a}$ \\
Fully open & $14.1 \pm 0.9 \mathrm{~b}$ & $87.3 \pm 4.2 \mathrm{~b}$ & $0.955 \pm 0.021 \mathrm{~b}$ \\
\hline
\end{tabular}

y Lesion area in square millimeters determined at 48 and $72 \mathrm{~h}$ postinoculation (hpi). Each value is the mean \pm standard error (SE) of at least 40 samples, using the same data set as in Table 2. Within-column values are significantly different using mixed model and Tukey's honestly significant difference (HSD) analyses within JMP Pro 12.0 at $P<0.0001$, as indicated by the letters. Lesion area values were transformed to the predicted lesion radius to better fit a normal distribution prior to analysis.

$\mathrm{z}$ Each value is the mean $\pm \mathrm{SE}$ of at least 60 samples from four trials, using the same data set as in Supplemental Table 3 . Within column values are significantly different using the mixed model and Tukey's HSD analyses within JMP Pro 12.0 on the log-transformed $390 / 480$ relative to mock values at $P \leq 0.024$, as indicated by the letters. 
of fruit extracts, as measured by several criteria (Mokrani et al. 2016). Surface diffusates from stage II fruit were less oxidizing as determined with the Pe299R/roGFP2 reporter than diffusates from the other stages (Fig. 7), suggesting that phenolic compounds (and perhaps other antioxidants in subtending cell layers) may subtly influence the redox environment at the fruit surface.

Although Bolinha fruit are more resistant to brown rot than Loadel fruit (Feliciano et al. 1987; Gradziel and Wang 1993) (Supplementary Fig. S3), we did not discern a difference within a given fruit stage between the two cultivars in the redox signal following exposure of the bioreporter to diffusates. Although a surface redox effect may be insufficient to explain cultivar differences in fruit resistance, there are several considerations that may account for ambiguity in our assessment. Our method of collecting the diffusates in this initial study may not be sufficiently aggressive to fully access the chemistry contributing to the redox environment extant at the time of the initial encounter or that would be generated by fungal propagules following attachment and penetration. Also, the assessment of fruit stage is somewhat subjective. We selected fruit based on sampling date and on their similar size and color. The latter features can be inherently difficult to match precisely with physiological and developmental maturity among peach genotypes. Finally, our sample size may have been insufficient to discern subtle differences between cultivars maintained under field conditions. As with many perennial crops, the logistical limitations with fruit-bearing peach trees constrain experimental studies and preclude maintaining trees within a well-controlled growth environment. Although it remains unresolved whether host cultivar differences in disease susceptibility are conditioned by the redox environment, the previously reported fruit stage-related changes in brown rot susceptibility and exocarp chemistry across both cultivars generally conform to the stagerelated differences in surface redox chemistry reported here with Pe229R/roGFP2 (Biggs and Northover 1988; Bostock et al. 1999; Gradziel et al. 1998; Lee and Bostock 2007; Senter and Callahan 1990).

Diffusates from peach flower petals from earlier-stage blossoms were significantly less oxidizing than fully open blossoms (Fig. 6). The rose flower petal data also bear this out and are further supported with lesion data, such that the petals from fully open flowers had more oxidizing diffusates and were more susceptible than partially open flowers. Our data are consistent with the rise in ROS that occurs during floral senescence (Rogers 2012) and the anticipated increase in disease susceptibility as flowers mature and senesce (Ferryman et al. 2002).

Under our experimental format, CA, CGA and ascorbic acid did not appear to directly lower the 390/480 value in treated Pe299R/ roGFP2 cells but mitigated the $\mathrm{H}_{2} \mathrm{O}_{2}$-induced oxidation of the bioreporter signal. The antioxidant buffering of ROS by phenols further illustrates, perhaps, an underappreciated role in signaling by these compounds, particularly because many of these traditionally are attributed to direct antimicrobial action in plant-microbe interactions (Hammerschmidt 2014). The impact on necrotrophic pathogens of host phenolic antioxidants such as CA and CGA may be to dampen ROS within the surface microenvironment and subtending cell layers during initial recognition and attempted penetration. There is growing acknowledgment that fungal pathogens may sense the initial redox state of the plant surface. They can modify it directly through ROS generation via NADPH oxidases or quench ROS by a variety of mechanisms (Heller and Tudzynski 2011). Of great interest in terms of understanding the transition from quiescence to activation of latent infections is whether fungi use redox sensing as a strategy to optimize their deployment of factors necessary for further ingress and colonization of their hosts.

The impact of CA, CGA, and related phenols on infection and disease that we have reported is not unique to $M$. fructicola. Villarino et al. (2011) found that melanin synthesis in M. laxa, another important causal agent of blossom blight and fruit brown rot in stone fruit, is inhibited by CGA and neo-CGA. CGA has also been found to inhibit synthesis of alternariol, a toxin important during pathogenesis of tomato fruit by Alternaria alternata (Wojciechowska et al. 2014). In B. cinerea transformed with roGFP2 as a reporter, appressorium development was associated with higher redox states (Heller et al. 2012), a result that is consistent with our observation that appressorium development in $M$. fructicola is suppressed by antioxidants and the surface environment of stage II peach fruit (Lee and Bostock 2006, 2007). We attempted to express roGFP2 in M. fructicola, as was done in B. cinerea (Heller et al. 2012), but we experienced issues with stability and uniformity of expression in conidia and hyphae and, thus, did not pursue this line of investigation further.

No doubt, we have only "scratched the surface" here in our initial investigation in the use of the Pe299R/roGFP2 reporter. However, the present study establishes a foundation for further development of redox biosensors for investigations in plant-microbe interactions. Pe299R/roGFP2 as a bioreporter is a noninvasive tool that can be complementary to traditional redox-sensitive chromophores and other chemical indices of redox states (Zulfugarov et al. 2011).

\section{ACKNOWLEDGMENTS}

We thank S. J. Remington, University of Oregon, for the gift of the plasmid pRSET-roGFP2; K. MacDonald for use of the SpectraMax M2 spectrofluorometer in her laboratory; N. McRoberts for advice on statistical analysis; G. Coaker for use of the luminometer; and A. Y. Burk for technical assistance in the luminol and redox electrode measurements.

\section{LITERATURE CITED}

Agrios, G. N. 2005. How plants defend themselves against pathogens. Pages 207-248 in: Plant Pathology, Fifth ed. Academic Press, San Diego, CA, U.S.A.

Alkan, N., Espeso, E. A., and Prusky, D. 2013. Virulence regulation of phytopathogenic fungi by $\mathrm{pH}$. Antioxid. Redox Signal. 19:1012-1025.

Andreotti, C., Ravaglia, D., Ragaini, A., and Costa, G. 2008. Phenolic compounds in peach (Prunus persica) cultivars at harvest and during fruit maturation. Ann. Appl. Biol. 153:11-23.

Arias-Barreiro, C. R., Okazaki, K., Koutsaftis, A., Inayat-Hussain, S. H., Tani, A., Katsuhara, M., Kimbara, K., and Mori, I. C. 2010. A bacterial biosensor for oxidative stress using the constitutively expressed redox-sensitive protein roGFP2. Sensors 10:6290-6306.

Bastos, E. L., Romoff, P., Eckert, C. R., and Baader, W. J. 2003. Evaluation of antiradical capacity by $\mathrm{H}_{2} \mathrm{O}_{2}$-hemin-induced luminol chemiluminescence. J. Agric. Food Chem. 51:7481-7488.

Biggs, A. R., and Northover, J. 1988. Early and late-season susceptibility of peach fruits to Monilinia fructicola. Plant Dis. 72:1070-1074.

Bostock, R. M., Wilcox, S. M., Wang, G., and Adaskaveg, J. E. 1999. Suppression of Monilinia fructicola cutinase production by peach fruit surface phenolic acids. Physiol. Mol. Plant Pathol. 54:37-50.

Buchholz, A. 2006. Characterization of the diffusion of non-electrolytes across plant cuticles: Properties of the lipophilic pathway. J. Exp. Bot. 57: 2501-2513.

Buta, G. J., and Spaulding, W. D. 1997. Endogenous levels of phenolics in tomato fruit during growth and maturation. J. Plant Growth Regul. 16:43-46.

Chiu, C. M., You, B. J., Chou, C. M., Yu, P. L., Yu, F. Y., Pan, S. M., Bostock, R. M., Chung, K. R., and Lee, M. H. 2013. Redox status-mediated regulation of gene expression and virulence in the brown rot pathogen Monilinia fructicola. Plant Pathol. 62:809-819.

Corduneanu, O., Janeiro, P., and Brett, A. M. O. 2006. On the electrochemical oxidation of resveratrol. Electroanalysis 18:757-762.

Díaz, A. N., Sanchez, F. G., and Garcia, J. A. G. 1996. Hydrogen peroxide assay by using enhanced chemiluminescence of the luminol- $\mathrm{H}_{2} \mathrm{O}_{2}$-horseradish peroxidase system: Comparative studies. Anal. Chim. Acta 327: 161-165.

Dooley, C. T., Dore, T. M., Hanson, G. T., Jackson, W. C., Remington, S. J., and Tsien, R. Y. 2004. Imaging dynamic redox changes in mammalian cells with green fluorescent protein indicators. J. Biol. Chem. 279:22284-22293.

Fatima, U., and Senthil-Kumar, M. 2015. Plant and pathogen nutrient acquisition strategies. Front. Plant Sci. 6:750.

Feliciano, A., Feliciano, A. J., and Ogawa, J. M. 1987. Monilinia fructicola resistance in the peach cultivar Bolinha. Phytopathology 77:776-780. 
Ferryman, S. A. M., Fitt, B. D. L., and Harold, J. F. S. 2002. Factors affecting the development of Botrytis cinerea (grey mould) on linseed (Linum usitatissimum) buds, flowers and capsules. Ann. Appl. Biol. 140:1-12.

Foyer, C. H., and Noctor, G. 2011. Ascorbate and glutathione: The heart of the redox hub. Plant Physiol. 155:2-18.

Gradziel, T. M., Bostock, R. M., and Adaskaveg, J. E. 1998. Resistance to brown rot disease in peach is determined by multiple structural and biochemical components. Acta Hortic. 622:347-352.

Gradziel, T. M., and Wang, D. 1993. Evaluation of brown rot resistance and its relation to enzymatic browning in clingstone peach germplasm. J. Am. Soc. Hortic. Sci. 118:675-679.

Guidarelli, M., Zubini, P., Nanni, V., Bonghi, C., Rasori, A., Bertolini, P., and Baraldi, E. 2014. Gene expression analysis of peach fruit at different growth stages and with different susceptibility to Monilinia laxa. Eur. J. Plant Pathol. 140:503-513.

Haas, H., Eisendle, M., and Turgeon, B. G. 2008. Siderophores in fungal physiology and virulence. Annu. Rev. Phytopathol. 46:149-187.

Halliwell, B., and Gutteridge, J. M. C. 2015. Free Radicals in Biology and Medicine, 5th ed. Oxford University Press, Oxford, U.K.

Hammerschmidt, R. 2014. Chlorogenic acid: A versatile defense compound. Physiol. Mol. Plant Pathol. 88:iii-iv.

Hansberg, W., and Aguirre, J. 1990. Hyperoxidant states cause microbial celldifferentiation by cell isolation from dioxygen. J. Theor. Biol. 142:201-221.

Hanson, G. T., Aggeler, R., Oglesbee, D., Cannon, M., Capaldi, R. A., Tsien, R. Y., and Remington, S. J. 2004. Investigating mitochondrial redox potential with redox-sensitive green fluorescent protein indicators. J. Biol. Chem. 279:13044-13053.

Heller, J., Meyer, A. J., and Tudzynski, P. 2012. Redox-sensitive GFP2: Use of the genetically encoded biosensor of the redox status in the filamentous fungus Botrytis cinerea. Mol. Plant Pathol. 13:935-947.

Heller, J., and Tudzynski, P. 2011. Reactive oxygen species in phytopathogenic fungi: Signaling, development, and disease. Annu. Rev. Phytopathol. 49: 369-390.

Ibbotson-Darhower, H., Hickey, K. D., and Tarvis, J. W. 1998. Susceptibility of peach and nectarine fruit at different developmental stages to Monilinia fructicola. (Abstr.) Phytopathology 88:S130.

Jersch, S., Scherer, C., Huth, G., and Schloesser, E. 1989. Proanthocyanidins as basis for quiescence of Botrytis cinerea in immature strawberry fruits. Z. Pflanzenkrankh. Pflanzenschutz 96:365-378.

Kerstiens, G. 1996. Signalling across the divide: A wider perspective of cuticular structure-function relationships. Trends Plant Sci. 1:125-129.

Kolattukudy, P. E., Rogers, L. M., Li, D., Hwang, C. S., and Flaishman, M. A. 1995. Surface signaling in pathogenesis. Proc. Natl. Acad. Sci. U.S.A. 92: 4080-4087.

Kubota, N., Mimura, H., and Shimamura, K. 2000. Differences in phenolic levels among mature peach and nectarine cultivars and their relation to astringency. J. Jpn. Soc. Hortic. Sci. 69:35-39.

Lee, M. H., and Bostock, R. M. 2006. Induction, regulation, and role in pathogenesis of appressoria in Monilinia fructicola. Phytopathology 96: 1072-1080.

Lee, M. H., and Bostock, R. M. 2007. Fruit exocarp phenols in relation to quiescence and development of Monilinia fructicola infections in Prunus spp.: A role for cellular redox? Phytopathology 97:269-277.

Lee, M. H., Chiu, C. M., Roubtsova, T., Chou, C. M., and Bostock, R. M. 2010. Overexpression of a redox-regulated cutinase gene, MfCUT1, increases virulence of the brown rot pathogen Monilinia fructicola on Prunus spp. Mol. Plant-Microbe Interact. 23:176-186.

Leveau, J. H. J., and Lindow, S. E. 2001. Appetite of an epiphyte: Quantitative monitoring of bacterial sugar consumption in the phyllosphere. Proc. Natl. Acad. Sci. U.S.A. 98:3446-3453.

Leveau, J. H. J., and Lindow, S. E. 2002. Bioreporters in microbial ecology. Curr. Opin. Microbiol. 5:259-265.

Lindow, S. E., and Brandl, M. T. 2003. Microbiology of the phyllosphere. Appl. Environ. Microbiol. 69:1875-1883.

Lohman, J. R., and Remington, S. J. 2008. Development of a family of redoxsensitive green fluorescent protein indicators for use in relatively oxidizing subcellular environments. Biochemistry 47:8678-8688.

Loper, J. E., and Buyer, J. S. 1991. Siderophores in microbial interactions on plant-surfaces. Mol. Plant-Microbe Interact. 4:5-13.

Martin, L. B. B., and Rose, J. K. C. 2014. There's more than one way to skin a fruit: Formation and functions of fruit cuticles. J. Exp. Bot. 65:4639-4651.

Mercier, J., and Lindow, S. E. 2000. Role of leaf surface sugars in colonization of plants by bacterial epiphytes. Appl. Environ. Microbiol. 66:369-374.

Meyer, A. J., Brach, T., Marty, L., Kreye, S., Rouhier, N., Jacquot, J. P., and Hell, R. 2007. Redox-sensitive GFP in Arabidopsis thaliana is a quantitative biosensor for the redox potential of the cellular glutathione redox buffer. Plant J. 52:973-986.

Meyer, A. J., and Dick, T. P. 2010. Fluorescent protein-based redox probes. Antioxid. Redox Signal. 13:621-650.
Mokrani, A., Krisa, S., Cluzet, S., Da Costa, G., Temsamani, H., Renouf, E., Mérillon, J.-M., Madani, K., Mesnil, M., Monvoisin, A., and Richard, T. 2016. Phenolic contents and bioactive potential of peach fruit extracts. Food Chem. 202:212-220.

Pensec, F., Pączkowski, C., Grabarczyk, M., Woźniak, A., Bénard-Gellon, M., Bertsch, C., Chong, J., and Szakiel, A. 2014. Changes in the triterpenoid content of cuticular waxes during fruit ripening of eight grape (Vitis vinifera) cultivars grown in the Upper Rhine Valley. J. Agric. Food Chem. 62: 7998-8007.

Pezet, R., Viret, O., Perret, C., and Tabacchi, R. 2003. Latency of Botrytis cinerea Pers.:Fr. and biochemical studies during growth and ripening of two grape berry cultivars, respectively susceptible and resistant to grey mould. J. Phytopathol. 151:208-214.

Podila, G. K., Rogers, L. M., and Kolattukudy, P. E. 1993. Chemical signals from avocado surface wax trigger germination and appressorium formation in Colletotrichum gloeosporioides. Plant Physiol. 103:267-272.

Prusky, D. 1996. Pathogen quiescence in postharvest diseases. Annu. Rev. Phytopathol. 34:413-434.

Prusky, D., and Yakoby, N. 2003. Pathogenic fungi: Leading or led by ambient $\mathrm{pH}$ ? Mol. Plant Pathol. 4:509-516.

Remus-Emsermann, M. N. P., and Leveau, J. H. J. 2010. Linking environmental heterogeneity and reproductive success at single-cell resolution. ISME J. 4:215-222.

Rodov, V., Benyehoshua, S., Fang, D. Q., Kim, J. J., and Ashkenazi, R. 1995. Preformed antifungal compounds of lemon fruit-Citral and its relation to disease resistance. J. Agric. Food Chem. 43:1057-1061.

Rogers, H. J. 2012. Is there an important role for reactive oxygen species and redox regulation during floral senescence? Plant Cell Environ. 35: 217-233

Ryffel, F., Helfrich, E. J. N., Kiefer, P., Peyriga, L., Portais, J.-C., Piel, J., and Vorholt, J. A. 2016. Metabolic footprint of epiphytic bacteria on Arabidopsis thaliana leaves. ISME J. 10:632-643.

Schwarzländer, M., Fricker, M. D., Müller, C., Marty, L., Brach, T., Novak, J., Sweetlove, L. J., Hell, R., and Meyer, A. J. 2008. Confocal imaging of glutathione redox potential in living plant cells. J. Microsc. 231:299-316.

Schwarzländer, M., Fricker, M. D., and Sweetlove, L. J. 2009. Monitoring the in vivo redox state of plant mitochondria: Effect of respiratory inhibitors, abiotic stress and assessment of recovery from oxidative challenge. Biochim. Biophys. Acta 1787:468-475.

Senter, S. D., and Callahan, A. 1990. Variability in the quantities of condensed tannins and other major phenols in peach fruit during maturation. J. Food Sci. 55:1585-1587.

Tecon, R., and Leveau, J. H. 2012. The mechanics of bacterial cluster formation on plant leaf surfaces as revealed by bioreporter technology. Environ. Microbiol. 14:1325-1332.

Tomás-Barberán, F. A., Gil, M. I., Cremin, P., Waterhouse, A. L., Hess-Pierce, B., and Kader, A. A. 2001. HPLC-DAD-ESIMS analysis of phenolic compounds in nectarines, peaches, and plums. J. Agric. Food Chem. 49: 4748-4760.

Villarino, M., Sandin-Espana, P., Melgarejo, P., and De Cal, A. 2011. High chlorogenic and neochlorogenic acid levels in immature peaches reduce Monilinia laxa infection by interfering with fungal melanin biosynthesis. J. Agric. Food Chem. 59:3205-3213.

Vorholt, J. A. 2012. Microbial life in the phyllosphere. Nat. Rev. Microbiol. 10:828-840.

Wang, G. Y., Michailides, T. J., Hammock, B. D., Lee, Y.-M., and Bostock, R. M. 2002. Molecular cloning, characterization, and expression of a redoxresponsive cutinase from Monilinia fructicola (Wint.) Honey. Fungal Genet. Biol. 35:261-276

Williams, B., Kabbage, M., Kim, H.-J., Britt, R., and Dickman, M. B. 2011. Tipping the balance: Sclerotinia sclerotiorum secreted oxalic acid suppresses host defenses by manipulating the host redox environment. PLoS Pathog. 7:e1002107.

Wojciechowska, E., Weinert, C. H., Egert, B., Trierweiler, B., Schmidt-Heydt, M., Horneburg, B., Graeff-Honninger, S., Kulling, S. E., and Geisen, R. 2014. Chlorogenic acid, a metabolite identified by untargeted metabolome analysis in resistant tomatoes, inhibits the colonization by Alternaria alternata by inhibiting alternariol biosynthesis. Eur. J. Plant Pathol. 139:735-747.

Yano, T., Oku, M., Akeyama, N., Itoyama, A., Yurimoto, H., Kuge, S., Fujiki, Y., and Sakai, Y. 2010. A novel fluorescent sensor protein for visualization of redox states in the cytoplasm and in peroxisomes. Mol. Cell. Biol. 30: 3758-3766.

Yu, P. L., Wang, C. L., Chen, P. Y., and Lee, M. H. 2017. The YAP1 homologmediated redox sensing is crucial for a successful infection by Monilinia fructicola. Mol. Plant Pathol. 18:783-797.

Zucconi, F. 1986. Peach. Page 568 in: Handbook of Fruit Set and Development. S. P. Monselise, ed. CRC Press, Inc., Boca Raton, FL, U.S.A.

Zulfugarov, I. S., Tovuu, A., Kim, J. H., and Lee, C. H. 2011. Detection of reactive oxygen species in higher plants. J. Plant Biol. 54:351-357. 